\title{
32. NEOGENE CALCAREOUS NANNOFOSSILS FROM THE MEDITERRANEAN-LEG 42A OF THE DEEP SEA DRILLING PROJECT
}

\author{
Carla Müller, Geologisch-Paläontologisches Institut der Universität Frankfurt am Main, \\ Frankfurt am Main, Germany
}

\begin{abstract}
This report summarizes results of investigations of nannofossils obtained from Leg 42A material (Malaga-Istanbul, April-May 1975). Nine holes were drilled at eight sites (Figure 1). Oldest sediments recovered are lower Miocene (Burdigalian). About 650 samples were studied using light microscope techniques. Age determinations are based on the standard nannofossil zonation (Martini, 1971). Deviations from this zonation, necessary in the Mediterranean, are described, and comparisons with other zonations applied to the region are discussed.
\end{abstract}

\section{INTRODUCTION}

Age determinations given in this report (Table 1) are based on the standard nannofossil zonation (Martini, 1971), which is very useful for the Pliocene and Quaternary. It is somewhat difficult to determine zones of the Miocene in the Mediterranean, because some of the index fossils are rare or missing. But with regard to the whole assemblages, the zones are recognizable, although the determination of boundaries is not always certain. Another difficulty in recognizing the Miocene zones is caused by the sometimes atypical shape of a species compared with specimens from tropical areas (mainly in the middle and upper Miocene). Heavy overgrowth (chiefly on discoasters) in some Miocene sediments, as well as the often large quantities of reworked species, further complicate the determination of zonal boundaries.

Stradner (1973) also used the standard nannofossil zonation for age determination of Leg 13 material. Bukry (1973) used his own zones and subzones, for the lower Pliocene and Quaternary, based on results of deep-sea cores from different areas. Such zonation does not permit a more detailed subdivision. Some of the subzones, which may be useful in areas of high species diversity and productivity, are not determinable in the Mediterranean. In contrast, observations of Schmidt (1973), in his zonation of middle Miocene and Pliocene sequences of Crete and the Aegean area, are important for other regions of the Mediterranean as well.

During recent years, a large number of contributions have been published describing nannofossil assemblages, mainly from the type sections of the Mediterranean and the Paratethys, to correlate and compare them from both areas: Martini (1968), Smith (1968), Cita et al. (1973), Cita and Gartner (1973), Rio (1974), Barbieri and Rio (1974), Martini (1973), Müller (1975), Martini and Müller (1975 a,b).

\section{BIOSTRATIGRAPHY}

As far as possible, the standard nannofossil zonation (Martini, 1971) was used for age determinations. Because of the scarcity or absence of some index fossils, other species were used to determine zones. Deviations from the standard zonation, necessary for the Mediterranean, are discussed below. Comparisons with other zonations described for this area (Cati and Borsetti, 1970; Bukry, 1973; Schmidt, 1973), and a correlation, are given in Table 2.

\section{Triquetrorhabdulus carinatus Zone (NN 1)}

Definition: Interval from the last occurrence of Helicosphaera recta to the first occurrence of Discoaster druggii.

Remarks: Probably only the upper part of this zone was recovered at Site 372. Discoaster druggii is not very useful in determining the top of this zone in the Mediterranean, because this species occurs only sporadically. This is also reported by Martini (1973). Therefore, the first (rare) occurrence of Helicosphaera ampliaperta was used to define the boundary between the Triquetrorhabdulus carinatus Zone (NN 1) and the Discoaster druggii Zone (NN 2). According to the standard nannofossil zonation, this species occurs first at or near this boundary.

\section{Discoaster druggii Zone (NN 2)}

Definition: Interval from the first occurrence of Discoaster druggii to the last occurrence of Triquetrorhabdulus carinatus.

Remarks: The base of this zone is defined in this report by the first occurrence of Helicosphaera ampliaperta, and the top by the common occurrence of this species. The upper boundary is of course somewhat uncertain. The extinction of Triquetrorhabdulus carinatus cannot be used because this species is missing in most parts of the Mediterranean, as well as in the 


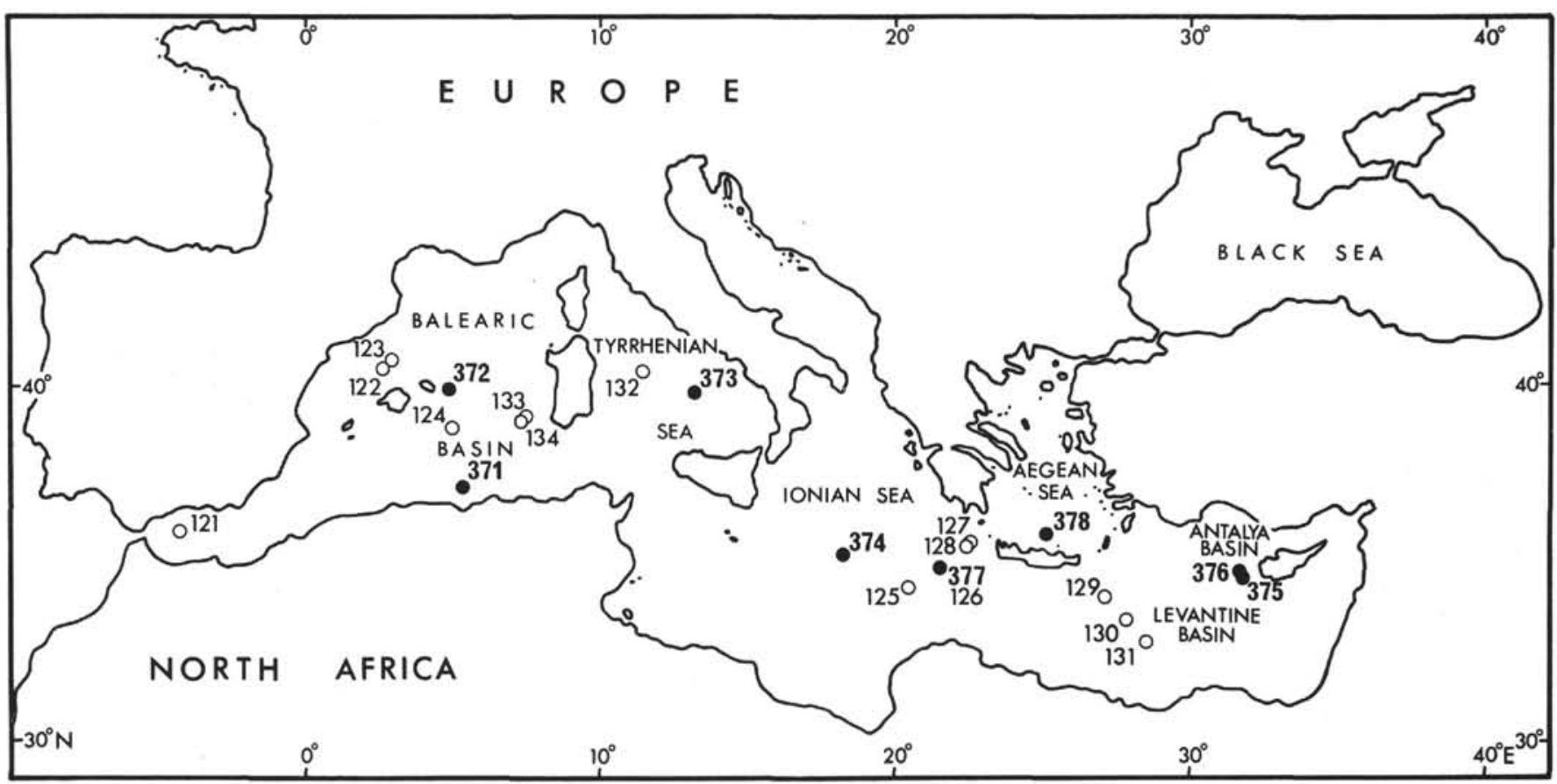

Figure 1. Location of Leg $42 A$ sites (•), together with those of the previous Leg 13 cruise (O).

Paratethys. It is reported by Martini (1974) from Spain, where few specimens were found, and by BaldiBeke (1975) from the upper Oligocene of Hungary.

\section{Sphenolithus belemnos Zone (NN 3)}

Definition: Interval from the last occurrence of Triquetrorhabdulus carinatus to the last occurrence of Sphenolithus belemnos.

Remarks: The top of this zone at Site 372 was defined by the first occurrence of Sphenolithus heteromorphus, although according to the standard zonation this species has its first occurrence in the upper part of the zone. Sphenolithus belemnos was not found at Site 372 , and seems to be missing in some parts of the western Mediterranean; but it is reported by Martini (1973) from Italy.

Sphenolithus belemnos is common in the eastern Mediterranean (Site 375) and land sections of Cyprus, and is rare in the Paratethys.

\section{Helicosphaera ampliaperta Zone (NN 4)}

Definition: Interval from the last occurrence of Sphenolithus belemnos to the last occurrence of Helicosphaera ampliaperta.

Remarks: This zone, determined at Site 372, includes the interval with Helicosphaera ampliaperta and Sphenolithus heteromorphus. Since Sphenolithus heteromorphus has its first occurrence in the upper part of the Sphenolithus belemnos Zone (NN 3), the Helicosphaera ampliaperta Zone as used here includes a larger interval than given by the standard zonation.

\section{Sphenolithus heteromorphus Zone (NN 5)}

Definition: Interval from the last occurrence of Helicosphaera ampliaperta to the last occurrence of Sphenolithus heteromorphus.
Remarks: This zone is easy to recognize in the Mediterranean. Sphenolithus heteromorphus, which has its last abundant occurrence at the top of this zone, was found in very few samples in the Discoaster exilis Zone (NN 6) and Discoaster kugleri Zone (NN 7) at Site 372. This was also observed in the Paratethys (Rögl and Müller, 1976) and in the material from Trinidad (Müller, unpublished). Sphenolithus heteromorphus has a later occurrence in the Paratethys than in the Mediterranean.

\section{Discoaster exilis Zone (NN 6)}

Definition: Interval from the last occurrence of Sphenolithus heteromorphus to the first occurrence of Discoaster kugleri.

Remarks: The assemblage of this zone consists, besides many long-ranging species like Coccolithus pelagicus, Reticulofenestra pseudoumbilica, Sphenolithus abies, Helicosphaera carteri, Cyclococcolithus macintyrei, Rhabdosphaera stylifer, Cyclococcolithus rotula, of Discoaster exilis, Discoaster subsurculus, Discoaster deflandrei, and few specimens of Coccolithus abisectus, which has its last occurrence within this zone. Coronocyclus cf. C. nitescens (oval) seems to be typical for this zone (Müller, 1974). Abundance of discoasters is inconsistent in the Mediterranean; they are extremely rare or missing in the Paratethys (Müller, 1974).

\section{Discoaster kugleri Zone (NN 7)}

Definition: Interval from the first occurrence of Discoaster kugleri to the first occurrence of Catinaster coalitus.

Remarks: The assemblage consists of the same species as those of the Discoaster exilis Zone (NN 6), plus Discoaster kugleri, which in general is scarce and 
TABLE 1

Zonal and Geological Age Assignments of Leg 42A Cores Based on Calcareous Nannofossils

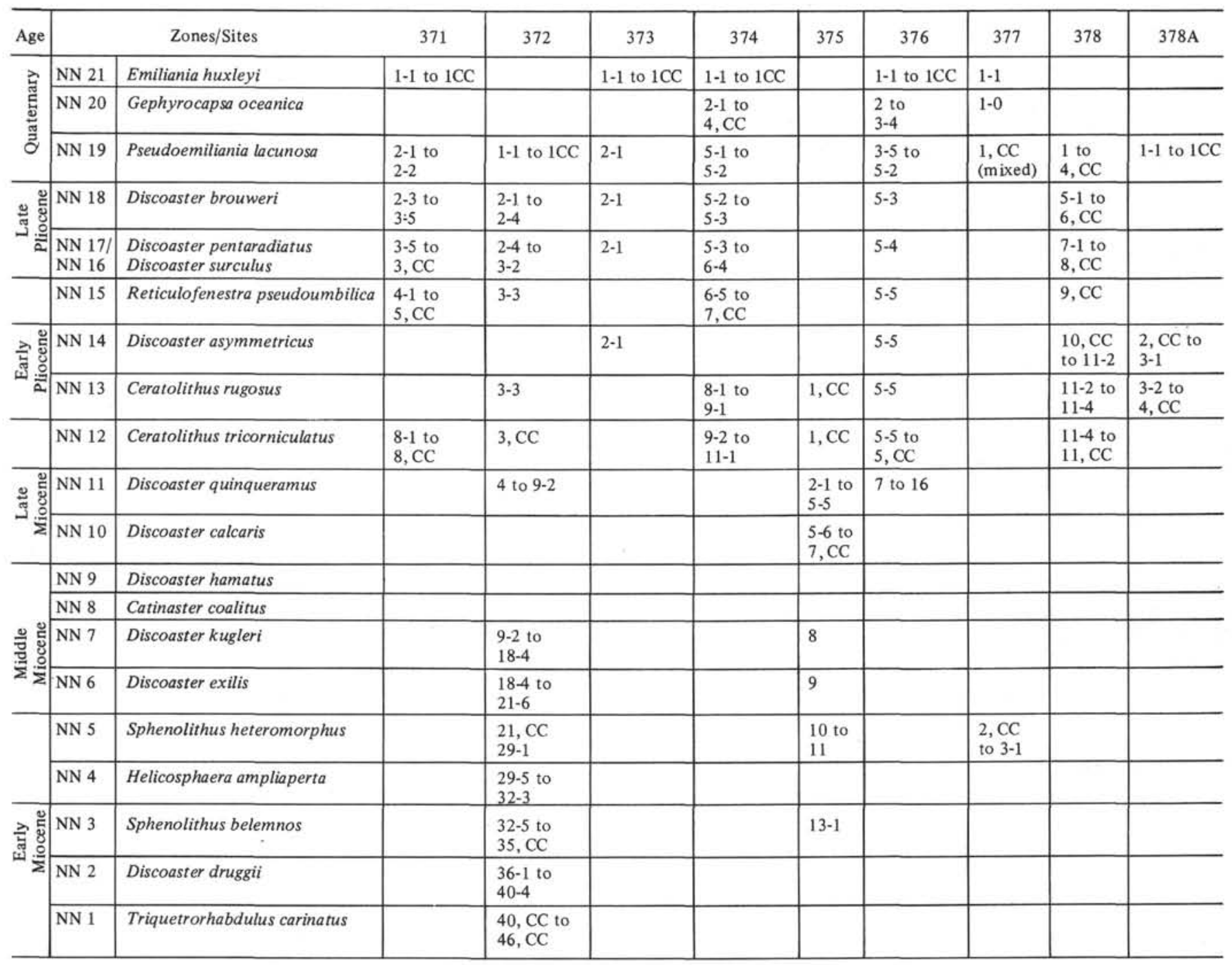

is not always typically developed. Consequently the identification is somewhat difficult. The arms of Mediterranean specimens are much longer than those of specimens from tropical regions. The Mediterranean specimens are similar to forms described from Mohole Drilling (Martini and Bramlette, 1963). The top of the Discoaster kugleri Zone cannot be recognized by the first occurrence of Catinaster coalitus, because this latter species is missing in the Mediterranean. Therefore, the top of the zone, as used here, is determined by the last occurrence of Discoaster kugleri, which according to the standard zonation has its last occurrence within the Catinaster coalitus Zone (NN 8). That means that in this report at least a part of the Catinaster coalitus Zone (NN 8) is included in the Discoaster kugleri Zone.

\section{Catinaster coalitus Zone (NN 8)}

Definition: Interval from the first occurrence of Catinaster coalitus to the first occurrence of Discoaster hamatus.
Remarks: This zone, on the basis of its original definition, was not recognized in Leg $42 \mathrm{~A}$ material, because Catinaster coalitus was absent. Forms mentioned by Martini (1971) from Breznita (Rumania), and probably those mentioned by Stradner (1973), belong to the Discoaster musicus group. The lower part of the Catinaster coalitus Zone with Discoaster kugleri is included in the Discoaster kugleri Zone as used in the present report.

\section{Discoaster hamatus Zone (NN 9)}

Definition: Interval from the first to the last occurrence of Discoaster hamatus.

Remarks: This zone, determined in the lowermost part of the type Tortonian (Martini, 1975), was not encountered during Leg 42A. According to Martini (1975), Discoaster hamatus is rare in the Mediterranean and smaller than in other regions. Also, Discoaster bollii is not known from the Mediterranean.

Comparison: Schmidt (1973) introduced for this stratigraphic interval the Discoaster aulakos-divaricatus Assemblage Zone. This zone is provisionally defined 
TABLE 2

Correlation of Nannofossil Zonations Used in the Mediterranean

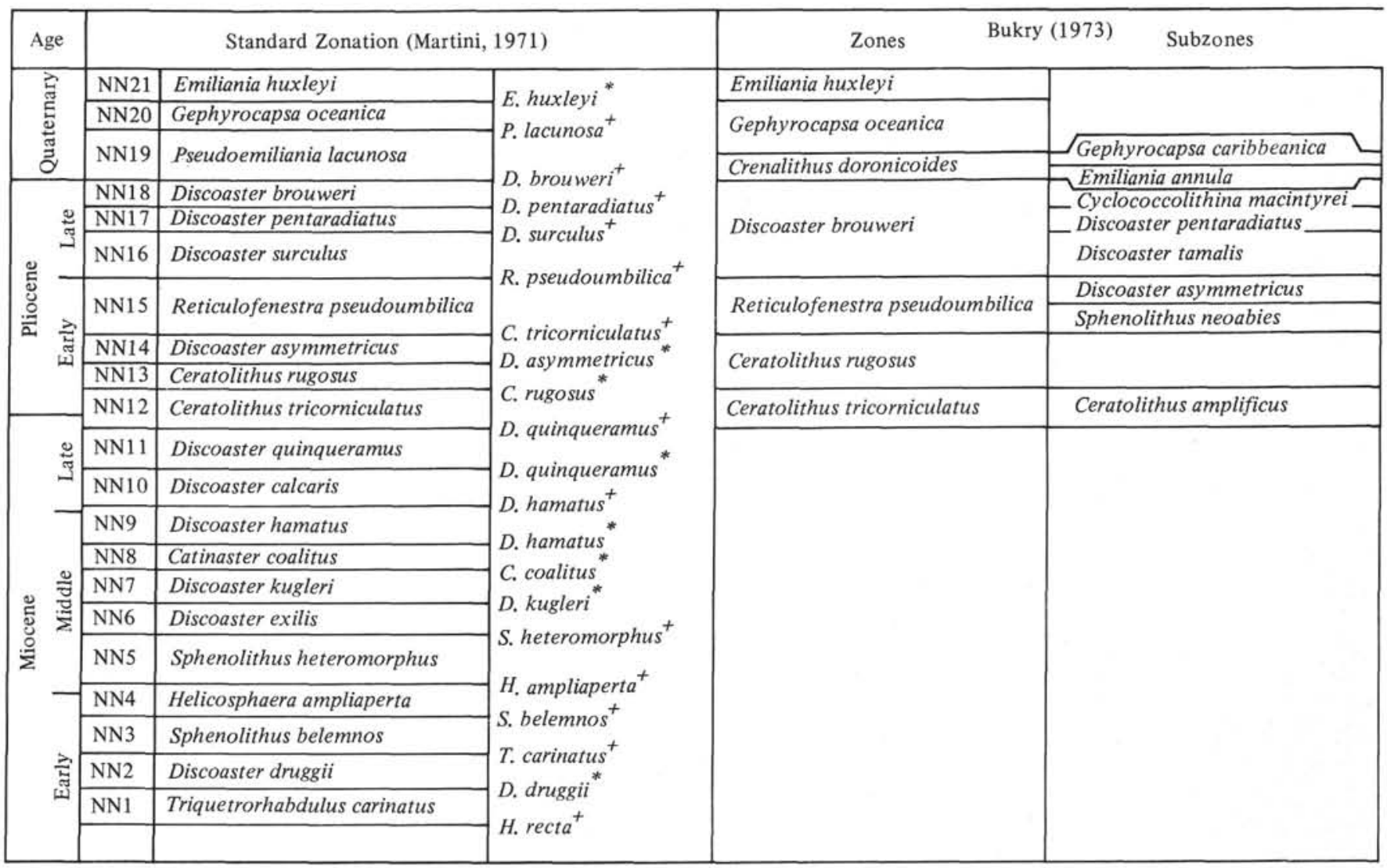

$*=$ First occurrence

$+=$ Last occurrence

by the presence of both zonal markers prior to the appearance of Discoaster pentaradiatus. Schmidt gives an assemblage of Discoaster aulakos, Discoaster deflandrei, Discoaster divaricatus, Discoaster exilis, Discoaster subsurculus, and Discoaster challengeri. This zone is correlated with the Discoaster phyllodus Zone of Cati and Borsetti (1970).

\section{Discoaster calcaris Zone (NN 10)}

Definition: Interval from the last occurrence of Discoaster hamatus to the first occurrence of Discoaster quinqueramus.

Remarks: The exact determination of the base, as well as the top of the Discoaster calcaris Zone is difficult because both index fossils are scarce. Also, the shape of Discoaster calcaris is frequently atypical. Other species of this zone are Discoaster pentaradiatus, Discoaster variabilis, and Discoaster brouweri. Discoaster exilis is missing.

Comparison: The Discoaster pentaradiatus Interval Zone given by Schmidt (1973), defined by the first occurrence of Discoaster pentaradiatus and the first occurrence of Discoaster quinqueramus, can be correlated with the Discoaster calcaris Zone (NN 10) and is comparable with the Discoaster pentaradiatus Zone of Cati and Borsetti (1970).

\section{Discoaster quinqueramus Zone (NN 11)}

Definition: Interval from the first to the last occurrence of Discoaster quinqueramus.

Remarks: The boundary between the Tortonian and the Messinian lies within this zone. The assemblage is sometimes strongly reduced in this zone, mainly in the upper part (corresponding to the Messinian), and Discoaster quinqueramus is scarce or missing. Because of its variable shape, this species cannot always be identified with certainty. Specimens here are smaller and the central knob is not as distinctly developed as in those of tropical areas. Ceratolithus tricorniculatus, which ordinarily has its first occurrence in the lower part of the Discoaster quinqueramus Zone, is rare or missing in this zone. The assemblage is distinguished by species of the Discoaster variabilis group, Discoaster icarus, Discoaster pentaradiatus, Discoaster surculus (scarce), and Triquetrorhabdulus rugosus, which becomes extinct near the top of this zone and may be useful to determine the approximate top of the Discoaster quinqueramus Zone in cases where the index fossil is missing.

Comparison: The Discoaster quinqueramus Interval Zone (Schmidt, 1973) is defined as the interval from the first occurrence of Discoaster quinqueramus to the first occurrence of Ceratolithus amplificus $(=C$. acutus; 
TABLE 2 - Continued

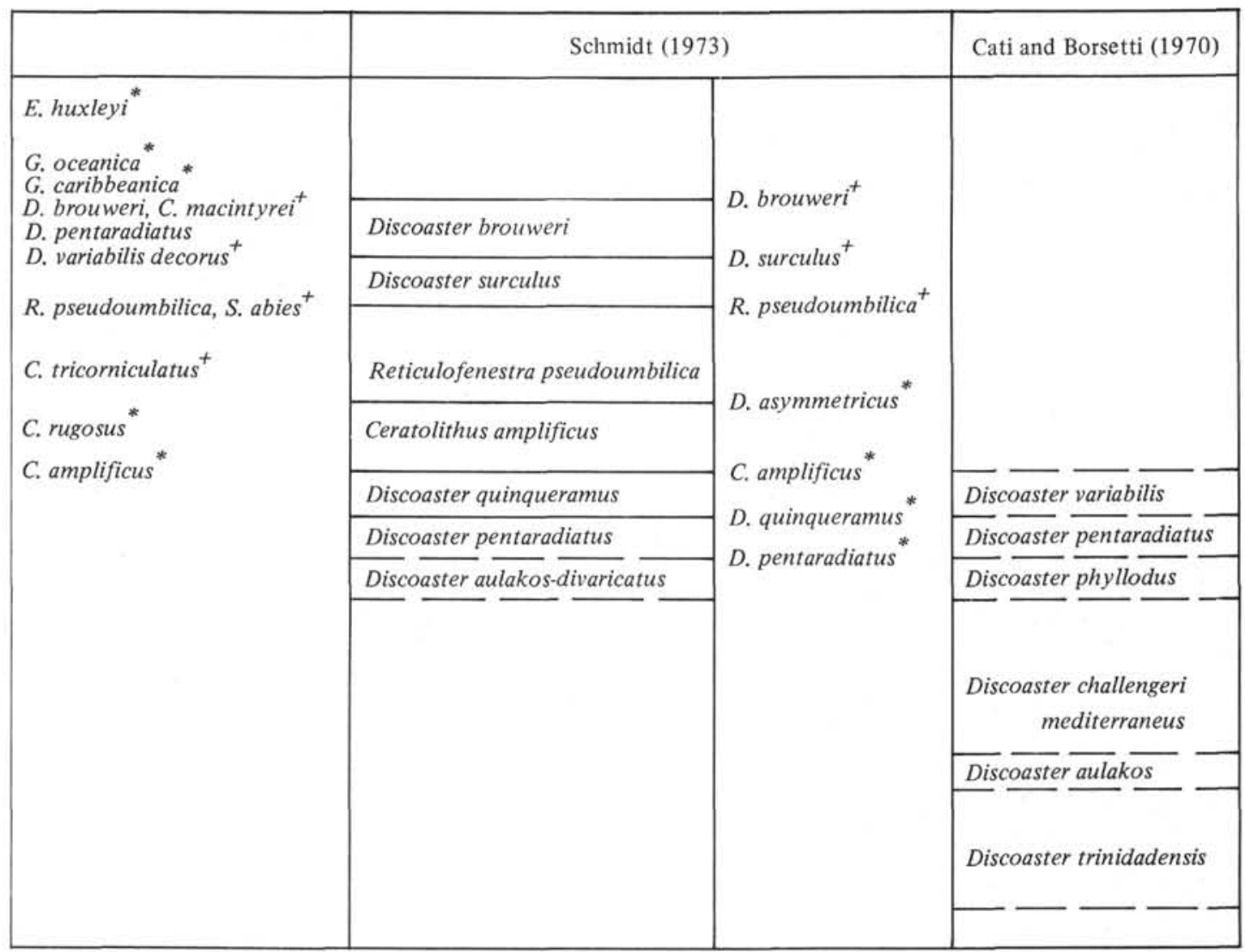

Gartner and Bukry, 1975). Ceratolithus acutus is not very useful as an index fossil in the Mediterranean, because it is very scarce and frequently completely absent there (Bukry, 1973). According to Bukry (1973), the first occurrence of Ceratolithus acutus corresponds approximately to the extinction of Triquetrorhabdulus rugosus. This event seems to be recorded in the uppermost part of the Discoaster quinqueramus Zone (NN 11), so that the Discoaster quinqueramus Interval Zone (Schmidt, 1973) can be correlated approximately with the Discoaster quinqueramus Zone (NN 11).

Only two species of Ceratolithus acutus were found in the upper part of the Discoaster quinqueramus Zone (NN 11) at Site 372.

\section{Ceratolithus tricorniculatus Zone (NN 12)}

Definition: Interval from the last occurrence of Discoaster quinqueramus to the first occurrence of Ceratolithus rugosus.

Remarks: This zone, in general, is rich in nannofossils and the fauna is of high diversity. Recognition of the base and top is sometimes difficult because both index fossils are generally rare in the Mediterranean. Ceratolithus tricorniculatus sometimes occurs frequently in this zone; both varieties (with and without the horn) were found in the same sample.
Comparison: The Ceratolithus tricorniculatus Zone (NN 12) corresponds approximately to the Ceratolithus amplificus Subzone (Bukry, 1973), which is distinguished by the presence of Ceratolithus acutus. Since C. acutus is missing or is present only sporadically in the Mediterranean (Bukry, 1973), this subzone is not very useful. The top of the Ceratolithus amplificus Subzone (Bukry, 1973) is defined by the first occurrence of Ceratolithus rugosus, and corresponds to the top of the Ceratolithus tricorniculatus Zone (NN 12).

The Ceratolithus amplificus Interval Zone (Schmidt, 1973), defined as the interval from the first occurrence of Ceratolithus amplificus to the first occurrence of Discoaster asymmetricus, includes the uppermost part of the Discoaster quinqueramus Zone (NN 11), the Ceratolithus tricorniculatus Zone (NN 12), and the Ceratolithus rugosus Zone (NN 13) of the standard nannofossil zonation.

\section{Ceratolithus rugosus Zone (NN 13)}

Definition: Interval from the first occurrence of Ceratolithus rugosus to the first occurrence of Discoaster asymmetricus.

Remarks: This zone in general is easily recognized, but sometimes the base is difficult to determine because Ceratolithus rugosus is rare in the Mediterranean. $C$. 
rugosus is less abundant than Ceratolithus tricorniculatus, and scyphospheres are common in this zone.

Comparison: The Ceratolithus rugosus Zone (NN 13) can be correlated with the upper part of the Ceratolithus amplificus Interval Zone (Schmidt, 1973) and with the lower part of the Ceratolithus rugosus Zone (Bukry, 1973).

\section{Discoaster asymmetricus Zone (NN 14)}

Definition: Interval from the first occurrence of Discoaster asymmetricus to the last occurrence of Ceratolithus tricorniculatus.

Remarks: This zone is easy to recognize in the Mediterranean. Discoasters, ceratoliths, and scyphospheres are less abundant which reflects climatic fluctuations in the Pliocene.

Comparison: The Discoaster asymmetricus Zone (NN 14) corresponds to the upper part of the Ceratolithus rugosus Zone (Bukry, 1973). The top of the latter is also defined by the extinction of Ceratolithus tricorniculatus. The Discoaster asymmetricus Zone (NN 14) also corresponds to the lower part of the Reticulofenestra pseudoumbilica Interval Zone (Schmidt, 1973), defined as the interval from the first occurrence of Discoaster asymmetricus to the last occurrence of Reticulofenestra pseudoumbilica.

\section{Reticulofenestra pseudoumbilica Zone (NN 15)}

Definition: Interval from the last occurrence of Ceratolithus tricorniculatus to the last occurrence of Reticulofenestra pseudoumbilica.

Remarks: This zone is easily recognized in the Mediterranean. In the uppermost part, small specimens of Reticulofenestra pseudoumbilica are typical. An overlap of Pseudoemiliania lacunosa and Reticulofenestra pseudoumbilica (small forms) occurred in the uppermost part of the zone. Discoaster tamalis and scyphospheres are abundant in some horizons; this is characteristic for this zone.

Comparison: The Reticulofenestra pseudoumbilica Zone (NN 15) corresponds to the Reticulofenestra pseudoumbilica Zone (Bukry, 1973), which is subdivided into the Sphenolithus neoabies and Discoaster asymmetricus Subzones. The Reticulofenestra pseudoumbilica Zone (NN 15) can also be correlated with the upper part of the Reticulofenestra pseudoumbilica Interval Zone (Schmidt, 1973). Both authors reported abundant Discoaster tamalis in some horizons within this stratigraphic interval.

\section{Discoaster surculus Zone (NN 16)}

Definition: Interval from the last occurrence of Reticulofenestra pseudoumbilica to the last occurrence of Discoaster surculus.

Remarks: The uppermost part of this zone is distinguished by the scarcity or absence, in some horizons of Discoaster surculus and Discoaster pentaradiatus. This paucity is more distinct in the western Mediterranean. In conjunction with increasing number of scypho- spheres, Discoaster surculus is abundant from the middle part of this zone. The distribution of discoasters and scyphospheres reflects climatic conditions.

In this report, the Discoaster surculus Zone and the Discoaster pentaradiatus Zone are combined into the Discoaster surculus/Discoaster pentaradiatus Zone (NN 16/NN 17).

Comparison: The Discoaster surculus Zone (NN 16) corresponds to the Discoaster surculus Interval Zone (Schmidt, 1973) and to the Discoaster tamalis subzone and a part of the Discoaster pentaradiatus Subzone (Bukry, 1973). Bukry (1973) defined the top of the Discoaster tamalis Subzone by the last abundant occurrence of Discoaster tamalis. But this does not seem to be a very useful stratigraphic event, since the abundant occurrence of this species is typical for the Reticulofenestra pseudoumbilica Zone (NN 15) in the Mediterranean.

\section{Discoaster pentaradiatus Zone (NN 17)}

Definition: Interval from the last occurrence of Discoaster surculus to the last occurrence of Discoaster pentaradiatus.

Remarks: This zone is not recognized in this report, because Discoaster surculus and Discoaster pentaradiatus were always found together in the same samples. Therefore, both zones are combined into the Discoaster surculus/Discoaster pentaradiatus Zone (NN 16/NN 17).

Comparison: The Discoaster pentaradiatus Zone (NN 17) is included in the Discoaster brouweri Interval Zone (Schmidt, 1973). The Discoaster pentaradiatus Subzone (Bukry, 1973) corresponds to the uppermost part of the Discoaster surculus Zone (NN 16) and to the Discoaster pentaradiatus Zone (NN 17).

\section{Discoaster brouweri Zone (NN 18)}

Definition: Interval from the last occurrence of Discoaster pentaradiatus to the last occurrence of Discoaster brouweri.

Remarks: This zone is defined here as the interval from the last occurrence of Discoaster surculus and Discoaster pentaradiatus to the last occurrence of Cyclococcolithus macintyrei. The recognition of the top of the zone by the extinction of Discoaster brouweri is difficult in the western Mediterranean because discoasters are extremely rare or are missing in the uppermost Pliocene. Their disappearance is ecologically controlled, and therefore cannot be used in all regions to precisely determine the Pliocene/Pleistocene boundary. This zone is distinguished by the presence of Discoaster brouweri and Discoaster triradiatus, which are abundant in some horizons.

Comparison: The Discoaster brouweri Zone (NN 18 ), as defined by Martini and Worsley (1970), corresponds approximately to the Cyclococcolithus macintyrei Subzone (Bukry, 1973). The Discoaster brouweri Interval Zone (Schmidt, 1973) includes also the Discoaster pentaradiatus Zone (NN 17). 


\section{Pseudoemiliania lacunosa Zone (NN 19)}

Definition: Interval from the last occurrence of Discoaster brouweri to the last occurrence of Pseudoemiliania lacunosa.

Remarks: The base of this zone is defined here by the last occurrence of Cyclococcolithus macintyrei. In the western Mediterranean this event was related to an abrupt reduction of Coccolithus pelagicus (Sites 371 and 372). A Braarudosphaera bigelowii horizon, distinguished by common large specimens of this species in the lowermost part of the Pseudoemiliania lacunosa Zone, was observed at Site 371 and at Site 378.

Comparison: The Coccolithus doronicoides Zone of Bukry (1973), subdivided in the lower Emiliania annula and the upper Gephyrocapsa caribbeanica subzones, is indistinct in Mediterranean sections. According to Bukry (1973), the Emiliania annula Subzone is distinguished by the absence of discoasters and species of the genus Gephyrocapsa. But investigations of Leg $42 \mathrm{~A}$ material have shown that small representatives of this genus are present in the upper Pliocene. Thierstein (1974) also described a similar situation from the Indian Ocean and Rio (1974) noted it in the sections of Santa Maria di Catanzaro and Le Castella. The top of the Gephyrocospsa caribbeanica Subzone is defined by the first occurrence of Gephyrocapsa oceanica; this means that the Coccolithus doronicoides Zone (Bukry, 1973) can be correlated only with the lowermost part of the Pseudoemiliania lacunosa Zone (NN 19).

\section{Gephyrocapsa oceanica Zone (NN 20)}

Definition: Interval from the last occurrence of Pseudoemiliania lacunosa to the first occurrence of Emiliania huxleyi.

Remarks: In general, this zone is easily recognized in the Mediterranean. However, because of reworking of Pseudoemiliania lacunosa, it is sometimes difficult to precisely determine the base of the zone.

Comparison: This zone corresponds only to the upper part of the Gephyrocapsa oceanica Zone (Bukry, 1973).

\section{Emiliania huxleyi Zone (NN 21)}

Definition: Interval with Emiliania huxleyi.

Remarks: This zone is easy to recognize.

Comparison: The Emiliania huxleyi Zone (NN 21) corresponds to the Emiliania huxleyi Zone of Bukry (1973).

\section{SUMMARY OF SITES}

SITE 371

$\left(37^{\circ} 55.88^{\prime} \mathrm{N}, 05^{\circ} 15.55^{\prime} \mathrm{E}\right.$; water depth: $\left.2792 \mathrm{~m}\right)$

Quaternary sediments, recovered in Core 1 and in Core 2, Section 2, are rich in well-preserved nannofossils. Reworked species are more abundant in the upper (NN 20/NN 21) than in the lower Pleistocene (NN 19). A large variety of Braarudosphaera bigelowii occurs in the lowermost part of the Pseudoemiliania lacunosa Zone (NN 19) in a very distinct horizon which corresponds to the Braarudosphaera bigelowii horizon described by Stradner (1973) from the Tyrrhenian Sea (Site 132).

The Pliocene/Pleistocene boundary is recognized by the last occurrence of Cyclococcolithus macintyrei between Sections 2 and 3 of Core 2 which is accompanied by a distinct decrease of Coccolithus pelagicus. The last discoasters occur in Sample 3-5, 100-101 cm, which already belongs to the Discoaster surculus/ Discoaster pentaradiatus Zone (NN 16/NN 17). Their occurrence is restricted to some horizons and they are in general rare in the upper Pliocene at Site 371. The Reticulofenestra pseudoumbilica Zone (NN 15) is distinguished by the abundance of Discoaster tamalis. Oldest sediments at Site 371 are probably lower Pliocene (NN 12). The underlying sediments are barren of nannofossils, or contain only reworked Cretaceous and Paleogene species (Table 3).

\section{SITE 372}

$\left(40^{\circ} 01.86^{\prime} \mathrm{N}, 04^{\circ} 47.79^{\prime} \mathrm{E}\right.$; water depth: $\left.2699 \mathrm{~m}\right)$

The Pseudoemiliania lacunosa Zone (NN 19) of the Pleistocene was recovered in Core 1. Sediments are rich in well-preserved nannofossils.

Discoasters are rare in the upper Pliocene of Core 2, and Core 3, Section 2 (NN 16 to NN 18), but Cyclococcolithus macintyrei is abundant.

The strongly compressed lower Pliocene sequence from Section 3-3 to Sample 3, CC belongs to the Reticulofenestra pseudoumbilica Zone (NN 15), Ceratolithus rugosus Zone (NN 13), and Ceratolithus tricorniculatus Zone (NN 12).

The determination of the Miocene zonal boundaries is somewhat uncertain, because the index fossils are missing or are present only sporadically. Discoasters are often heavily overgrown, and their identification is difficult or even impossible. Core 4 to Sample 9-2, 49$50 \mathrm{~cm}$, belongs to the Discoaster quinqueramus Zone (NN 11). The sediments contain abundant slightly overgrown nannofossils, and the discoasters are strongly overgrown. Reworked Cretaceous and Eocene species occur rarely. Sample 8, CC is barren of nannofossils. Sections 9-1 and 9-2 are distinguished by fine laminated sediments. The white layers contain abundant nannofossils in an assemblage of low diversity. Sphenolithus abies and/or a very small species of Reticulofenestra are sometimes the only species occurring in these layers. The gray layers are marked by large amounts of detrital material and an increasing number of reworked species, fewer nannofossils, but a more diversified assemblage. This indicates a short influx of normal marine water during deposition of the gray layers. Discoasters are almost completely absent in the white layers and are scarce in the gray layers. Very few specimens of Ceratolithus tricorniculatus were found in this section. In Sample 9-2, 100-101 cm, the assemblages are more diverse. Nannofossils are abundant; discoasters in general are rare and badly preserved. 
TABLE 3

Nannofossil Distribution at Site 371

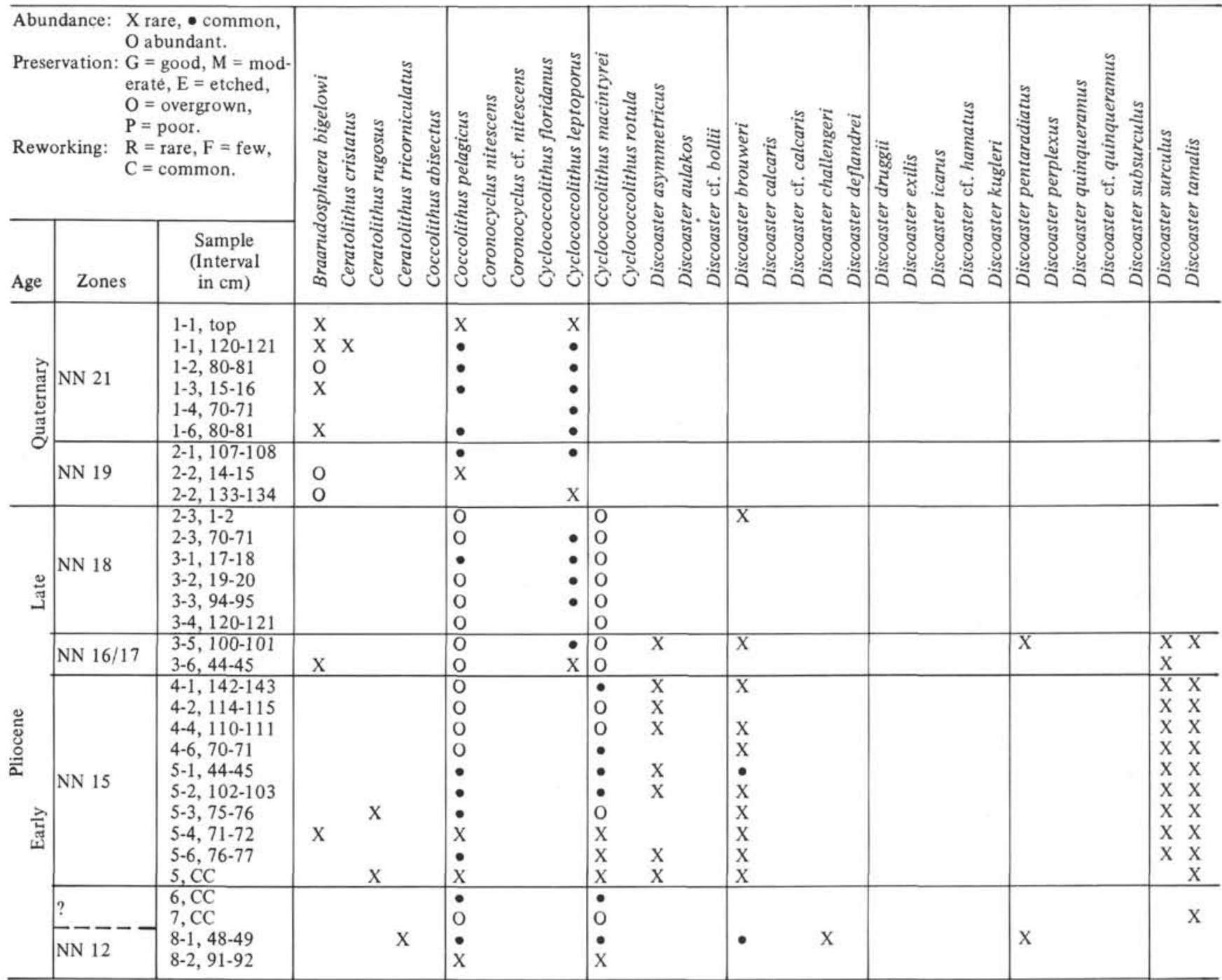

The interval from Sample 9-2, 100-101 cm to Sample $18-4,10-11 \mathrm{~cm}$ belongs to the Discoaster kugleri Zone (NN 7). This indicates a hiatus of at least 5 to 6 m.y. between Sample 9-2, 49-50 cm and Sample 9-2, $100-101 \mathrm{~cm}$.

The Discoaster exilis Zone (NN 6) extends from Sample 18-4, 100-101 cm to Section 21-6. Reworked Cretaceous and Eocene species are scarce.

The Sphenolithus heteromorphus Zone (NN 5) extends from Sample 21, CC to Section 29-1 and is rich in slightly overgrown nannofossils. The interval from Section 29-5 to Section 32-3 belongs to the Helicosphaera ampliaperta Zone (NN 4), and Section 32-5 to Sample 35, CC belongs to the Sphenolithus belemnos Zone (NN 3) although it does not contain Sphenolithus belemnos. Section 36-1 to Section 40-4 is assigned to the Discoaster druggii Zone (NN 2), and Sample $40, \mathrm{CC}$ to Sample 46, CC belongs to the upper part of the Triquetrorhabdulus carinatus Zone (NN 1). Recog- nition of this zone is complicated by the absence of index fossils. Sediments of the lower Burdigalian contain common reworked Cretaceous and Tertiary species which are less common in the upper part.

Table 4 shows the nannofossil distribution at Site 372.

SITE 373

$\left(39^{\circ} 43.68^{\prime} \mathrm{N}, 12^{\circ} 59.56^{\prime} \mathrm{E}\right.$; water depth: $\left.3517 \mathrm{~m}\right)$

Quaternary sediment was recovered in Core 1 which is rich in well-preserved nannofossils. A Pliocene breccia consisting of different types of sediments occurs in Core 2; it belongs to the Discoaster brouweri Zone (NN 18), Discoaster surculus/Discoaster pentaradiatus Zone (NN 16/NN 17), and Discoaster asymmetricus Zone (NN 14). The content of nannofossils is diluted in some samples by a large quantity of volcanic ash. Sediments included in the volcanic breccia of Cores 3 and 4 contain no nannofossils. 
TABLE 3 - Continued

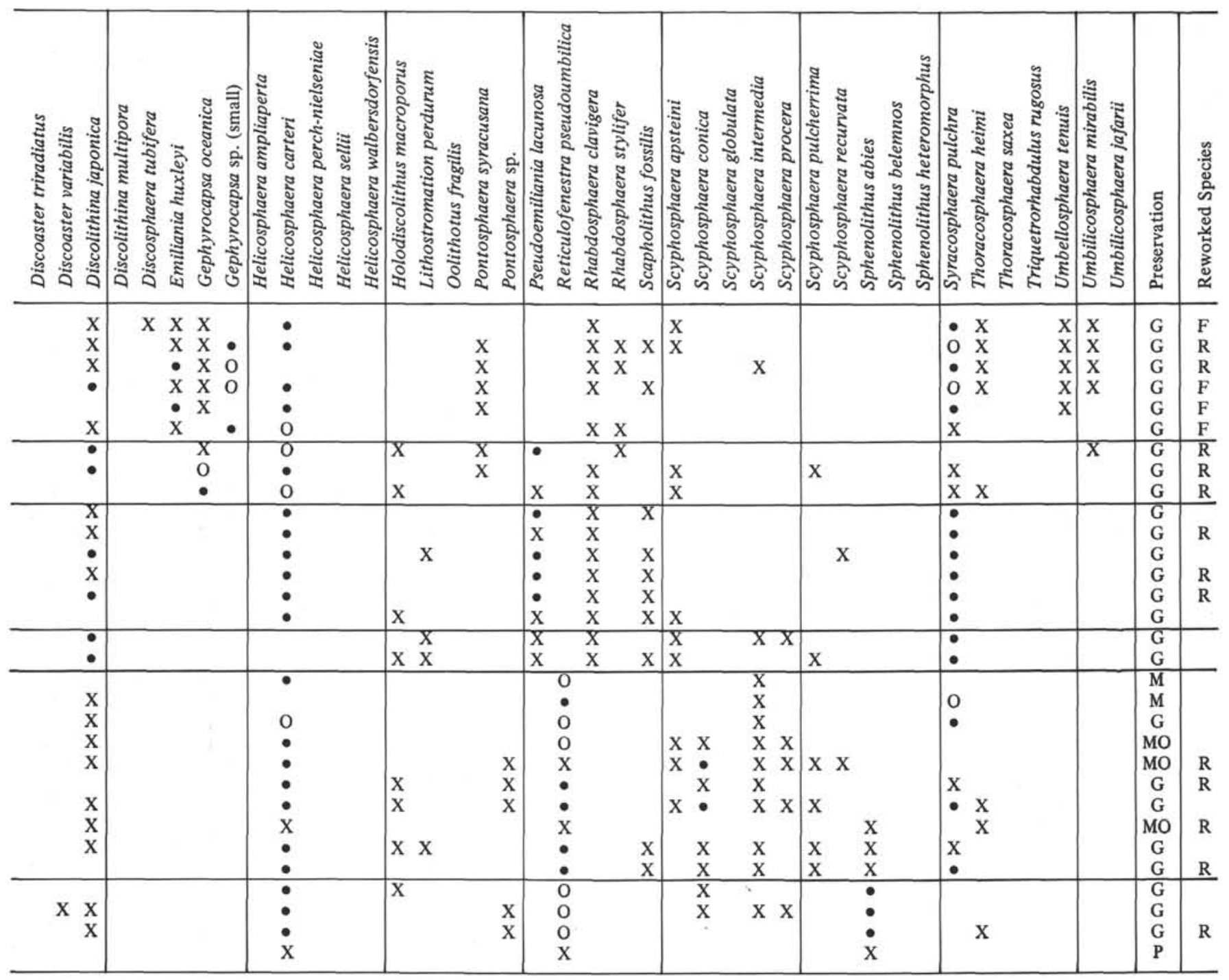

SITE 374

$\left(35^{\circ} 50.87^{\prime} \mathrm{N}, \mathbf{1 8}^{\circ} 11.78^{\prime} \mathrm{E}\right.$; water depth: $\left.4078 \mathrm{~m}\right)$

The interval from Core 1 to Core 3, Section 1 (NN 21 to NN 19) is Quaternary. Sediments are rich in well-preserved nannofossils, and reworked Neogene species occur frequently. The sapropel layers are rich in well-preserved to slightly etched nannofossils. Reworked species are less common in these layers. The Pseudoemiliania lacunosa Zone (NN 19) is marked by many reworked species. A small hiatus probably includes the lowermost part of the Pleistocene and probably the uppermost part of the Discoaster brouweri Zone (NN 18) of the Pliocene.

The precise determination of the uppermost Pliocene is difficult because of reworked species. Samples 5-2, 72-73 cm and 5-3, 10-11 cm are rich in Discoaster brouweri and Discoaster triradiatus, which are typical for the Discoaster brouweri Zone (NN 18).

The Discoaster surculus/Discoaster pentaradiatus Zone (NN 16/NN 17) includes the sequence from
Sample 5-3, 11-12 cm to Sample 6-4, 140-141 cm. Discoaster surculus is scarce in the upper part of this zone. Sediments are rich in well-preserved nannofossils. Coccoliths of the sapropel layers are etched, and there is an enrichment of discoasters owing to selective dissolution of the more fragile coccoliths.

The sequence from Sample 6-5, $38-39 \mathrm{~cm}$ to Sample Core 7, CC belongs to the Reticulofenestra pseudoumbilica Zone (NN 15). Discoaster tamalis is abundant in some layers.

The interval between Samples 8-1, 108-109 cm and 9-1, 130-131 cm belongs to the Ceratolithus rugosus Zone (NN 13). Sediments are rich in nannofossils which are sometimes slightly overgrown. Nannofossils in the sapropel layer are well-preserved.

The Ceratolithus tricorniculatus Zone (NN 12) extends from Core 9 to Core 11, Section 1. Sediments contain abundant well-preserved nannofossils; discoasters are often broken in the sapropel layers. Below Section 1, sediments are barren of nannofossils as a result of recrystallization (Table 5). 
TABLE 4

Nannofossil Distribution at Site 372

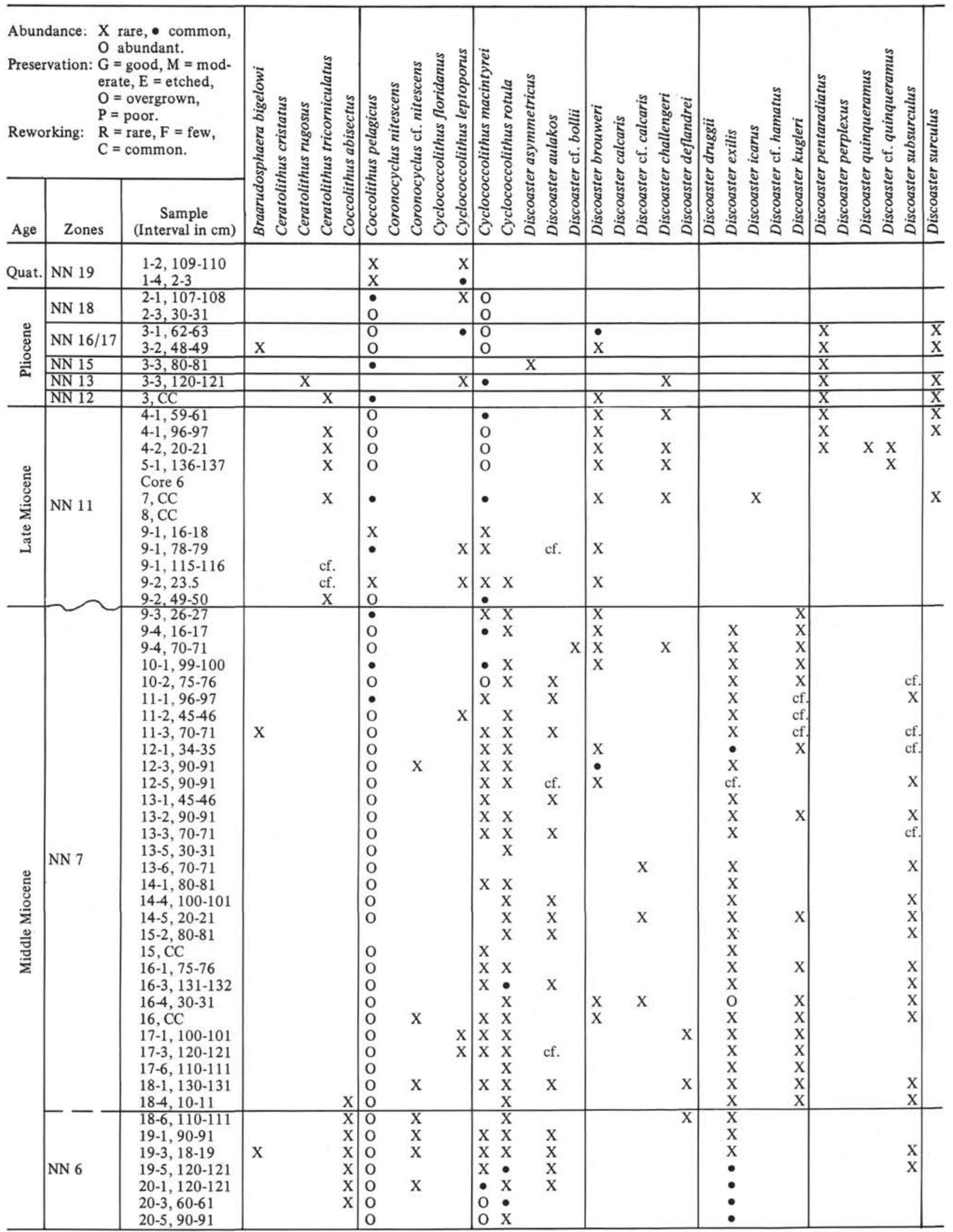


TABLE 4 - Continued

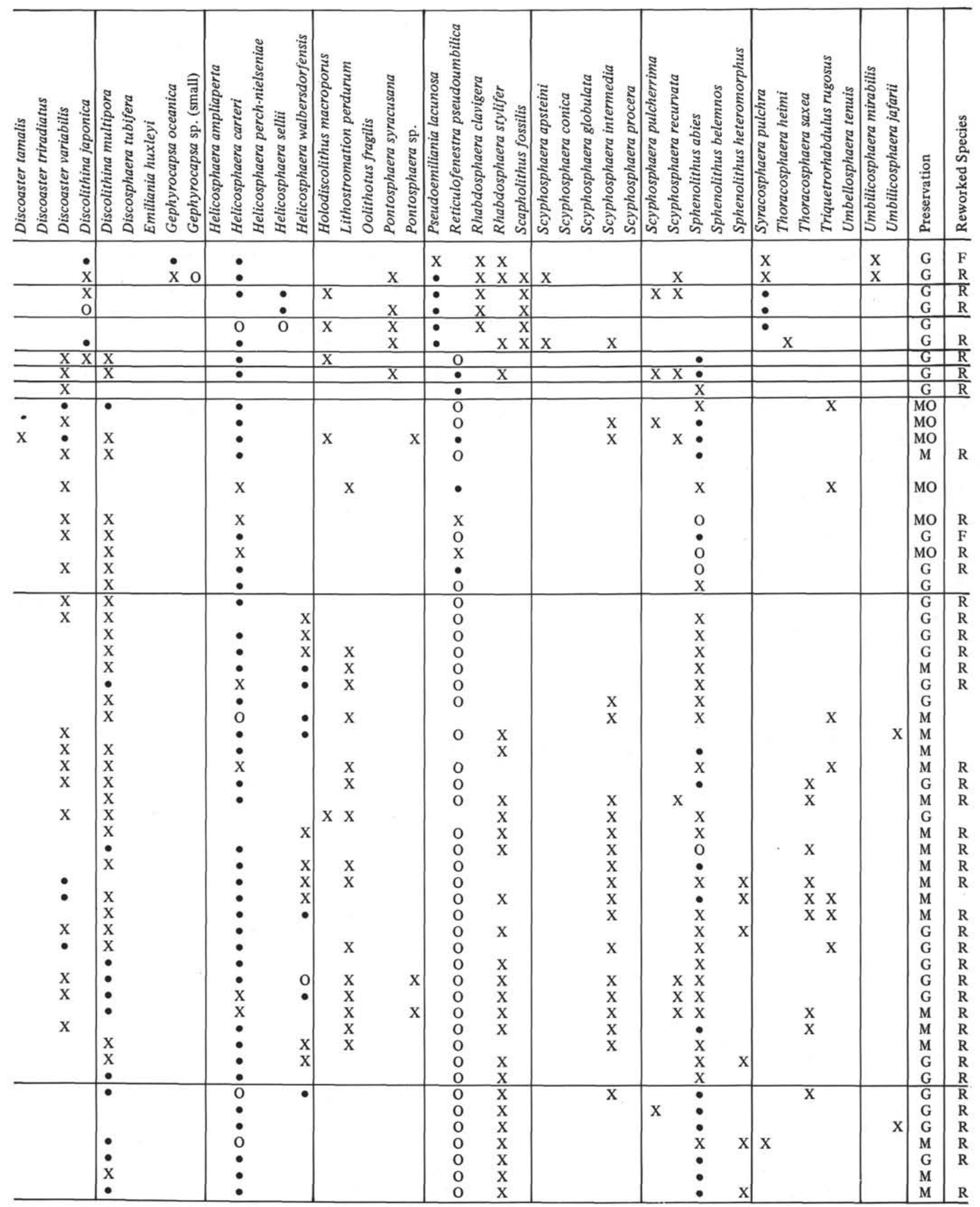


TABLE 4 - Continued

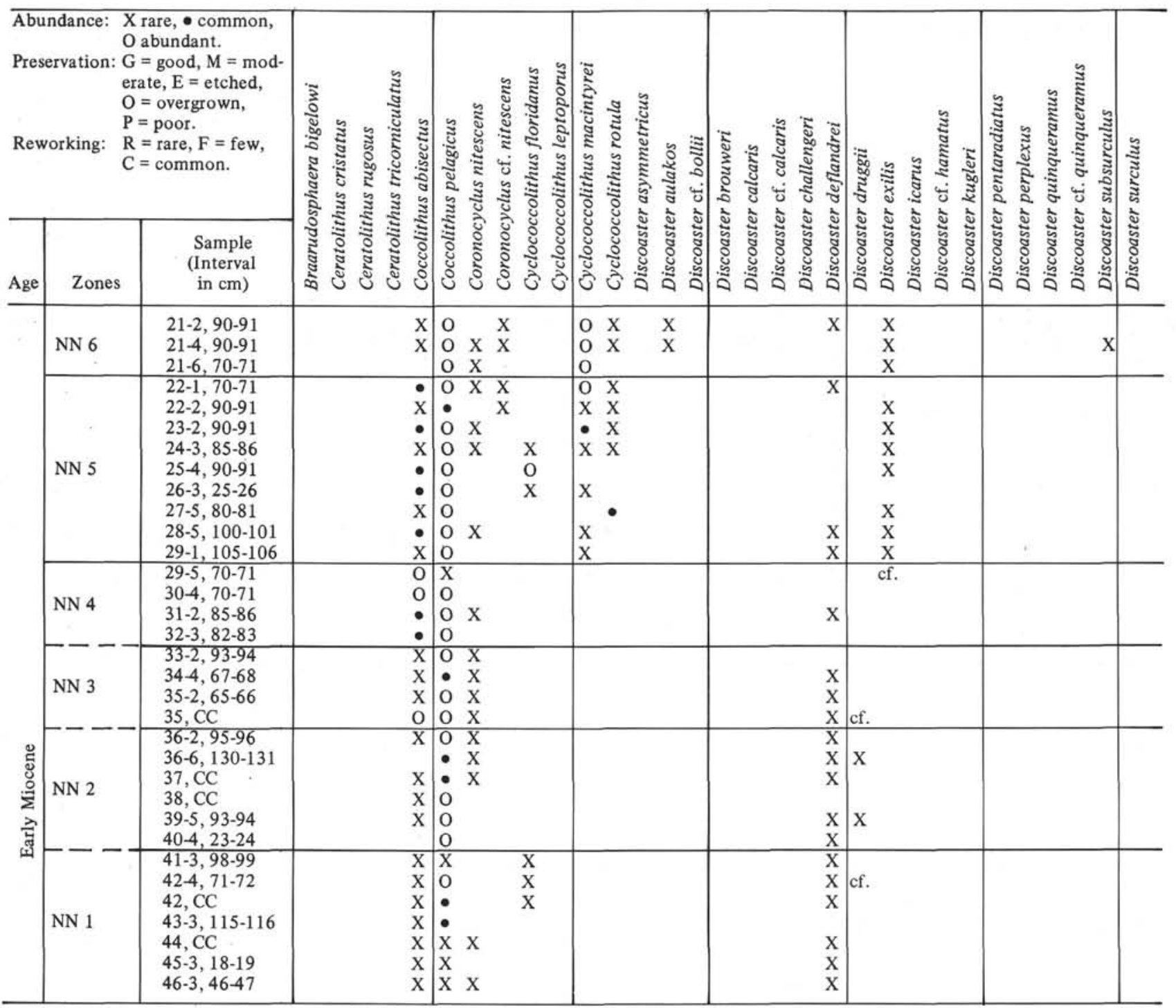

SITE 375

$\left(34^{\circ} 45.74^{\prime} \mathrm{N}, 30^{\circ} 45.58^{\prime} \mathrm{E}\right.$; water depth: $\left.1900 \mathrm{~m}\right)$

Lower Pliocene (NN 13 and NN 12) sediment, rich in well-preserved to slightly overgrown nannofossils, was recovered in Core 1. The nannofossils are rare at the base of Core 1 and in Core 2, Sections 2 and 3. In Sample 2-3, 93-94 cm, the assemblage is restricted to the small species of Reticulofenestra and Sphenolithus abies. Below, a highly diversified nannofossil assemblage, belonging to the Discoaster quinqueramus Zone (NN 11), is present. The quantity of nannofossils in Core 4 and Core 5 differs (NN 11). Reworked species of Cretaceous and Paleogene are rare. Sections 2 and 5 of Core 5 contain fewer nannofossils diluted by the large amount of detrital material, and reworked species are slightly more abundant.

Core 6 and Core 7, Sections 1 and 2 (Discoaster calcaris Zone, NN 10) are poor in nannofossils, but they become more abundant in the lower part of Core 7.
Core 8 belongs to the Discoaster kugleri Zone (NN 7), Core 9 to the Discoaster exilis Zone (NN 6). Discoasters are more abundant in Core 8 , and are slightly overgrown.

The Sphenolithus heteromorphus Zone (NN 5) occurs in Cores 10 and 11. Nannofossils are well preserved to slightly overgrown. The Sphenolithus belemnos Zone (NN 3) is recognized in Core 13, Section 1. Sediments contain abundant nannofossils (Table 6).

\section{SITE 376}

$\left(34^{\circ} 52.32^{\prime} \mathrm{N}, 3^{\circ}{ }^{\circ} 48.45^{\prime} \mathrm{E}\right.$; water depth: $\left.2101 \mathrm{~m}\right)$

Quaternary sediments were recovered in Core 1 to Core 5, Section 3, and in Core 6, Sections 1 to 3 . Sediments in general are rich in well-preserved nannofossils. Numbers of reworked species from the Cretaceous, Paleogene, and Neogene are variable. The Quaternary sequence is marked by the presence of sapropel layers. Reworked species are rare in these layers and abundant directly below them. This could be a result from changes of current patterns. The 
TABLE 4 - Continued

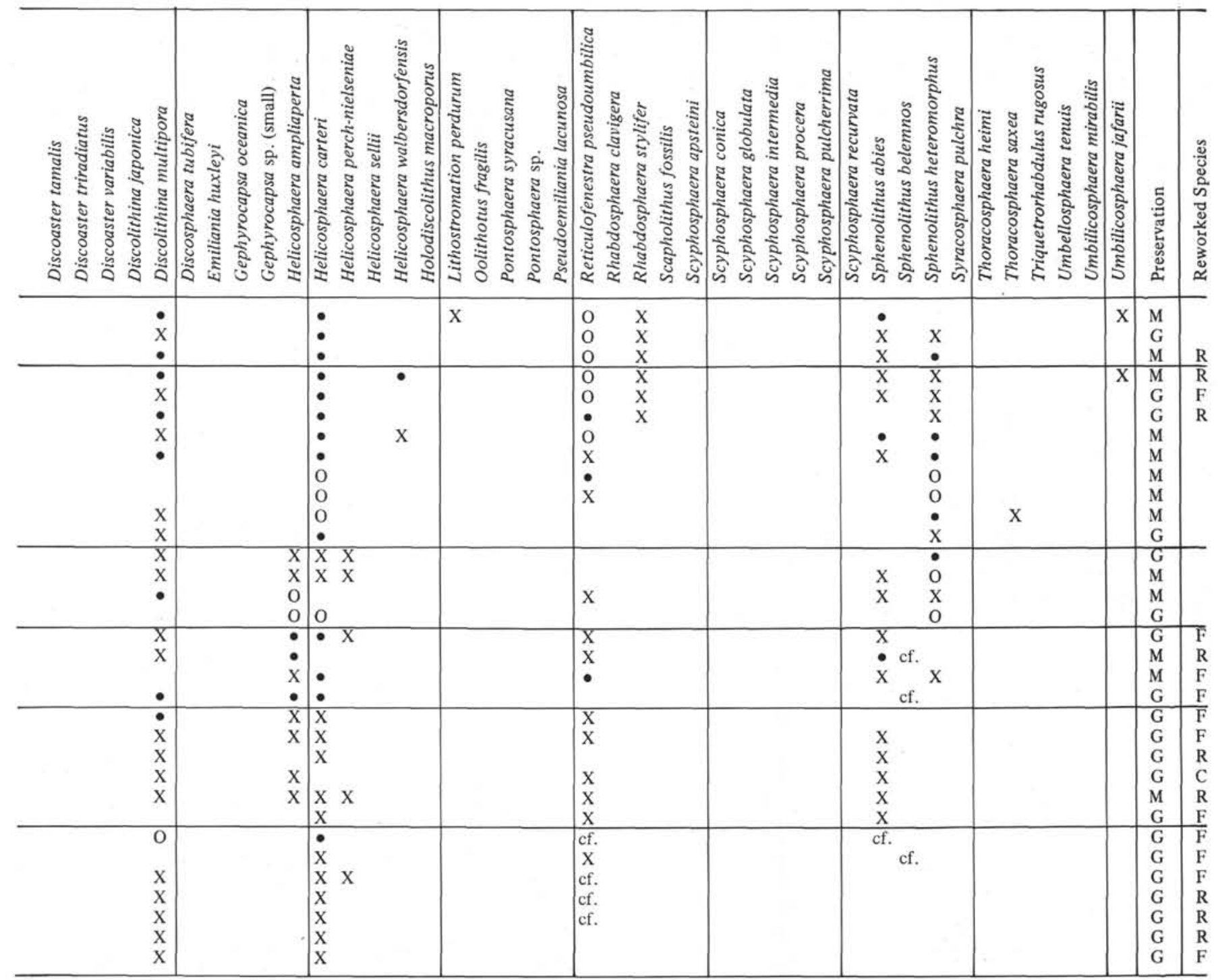

Pliocene is distinguished by an extremely reduced sequence. A small unconformity may exist including loss of the uppermost part of the Discoaster brouweri Zone (NN 18). Sediments are rich in well-preserved to slightly overgrown nannofossils. Discoasters are abundant throughout the Pliocene; they are enriched in some of the sapropel layers; the more fragile coccoliths show signs of dissolution. Reworked species are missing in the Pliocene sequence.

The Miocene section, consisting of dolomitic marls (Cores 7 to 16 ) overlying the evaporites, probably belong to the Discoaster quinqueramus Zone (NN 11). The assemblage consists of a few long-ranging species, together with many reworked species from the Cretaceous, Paleogene, and Miocene. The content of reworked species decrease toward the top of this sequence, which is related to an increase of idiomorphic dolomite crystals. In the evaporite breccia of Core 17, Section 1, a white pebble of nannofossil ooze was found, consisting of very small species of Reticulofenestra and Sphenoltithus abies. (Table 7).
Site 377

$\left(35^{\circ} 09.25^{\prime} \mathrm{N}, 2^{\circ} 25.86^{\prime} \mathrm{E}\right.$; water depth; $\left.3718 \mathrm{~m}\right)$

Core 1 belongs to the Pleistocene, and contains a mixed assemblage. In a gray pebble of Core 1 and Sample 1, CC, the assemblage of the Sphenolithus heteromorphus Zone (NN 5) is present. The same assemblage occurs in Cores 2 and 3. Sediments contain few, but well-preserved nannofossils. A few reworked species from the Cretaceous and Eocene are also present.

\section{SITE 378}

$\left(35^{\circ} 56.67^{\prime} \mathrm{N}, 2^{\circ} 06.97^{\prime} \mathrm{E}\right.$; water depth; $\left.1855 \mathrm{~m}\right)$

Quaternary (NN 19) sediment occurs from Core 1 to Sample 3, CC. Sediments are rich in nannofossils which are generally well-preserved but are slightly etched in the sapropel layers. The Braarudosphaera bigelowii horizon was recovered in Sample 3-3, 110$111 \mathrm{~cm}$. 
TABLE 5

Nannofossil Distribution at Site 374

\begin{tabular}{|c|c|c|c|c|c|c|c|c|c|c|}
\hline \multicolumn{3}{|c|}{$\begin{array}{ll}\text { Abundance: } & \mathrm{X} \text { rare, } \bullet \text { common, } \\
& \mathrm{O} \text { abundant. } \\
\text { Preservation: } & \mathrm{G}=\text { good, } \mathrm{M}=\text { mod- } \\
& \text { erate, } \mathrm{E}=\mathrm{etched}, \\
& \mathrm{O}=\text { overgrown, } \\
& \mathrm{P}=\text { poor. } \\
\text { Reworking: } & \mathrm{R}=\text { rare, } \mathrm{F}=\text { few } \\
& \mathrm{C}=\text { common }\end{array}$} & \multirow{2}{*}{ 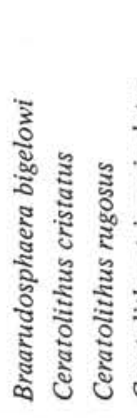 } & \multirow{2}{*}{ 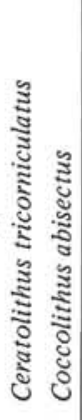 } & \multirow{2}{*}{ 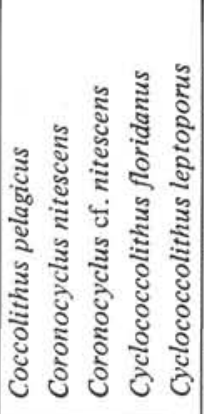 } & \multirow{2}{*}{ 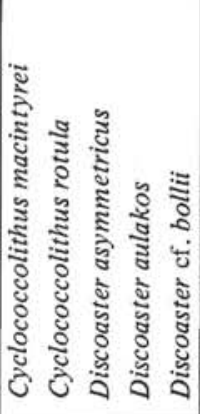 } & \multirow{2}{*}{ 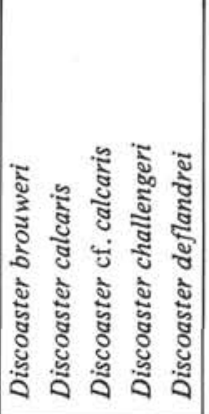 } & \multirow{2}{*}{ 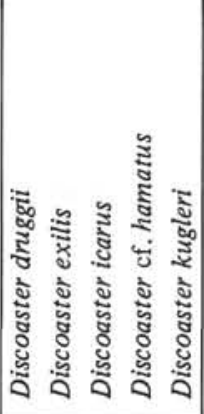 } & \multirow{2}{*}{ 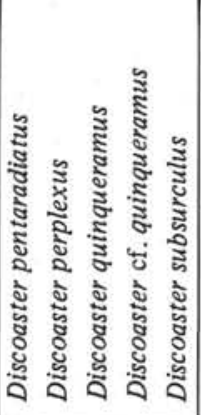 } & \multirow{2}{*}{ 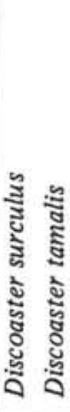 } \\
\hline Age & Zones & $\begin{array}{l}\text { Sample } \\
\text { (Interval } \\
\text { in } \mathrm{cm} \text { ) }\end{array}$ & & & & & & & & \\
\hline \multirow{3}{*}{ 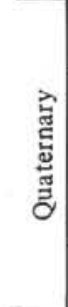 } & NN 21 & $\begin{array}{l}1-1,40-41 \\
1-2,56-57 \\
\end{array}$ & $\mathrm{X}$ & & $\begin{array}{l}\mathrm{X} \\
\mathrm{X}\end{array}$ & & & & & \\
\hline & NN 20 & $\begin{array}{l}2-1,75-76 \\
2-2,51-52 \\
2-3,23-24 \\
3-1,105-106 \\
4-2,59-60 \\
4-458-59 \\
\end{array}$ & $\begin{array}{ll}\mathrm{X} & \mathrm{X} \\
\mathrm{X} & \mathrm{X} \\
& \mathrm{X} \\
& \mathrm{X} \\
\mathrm{X} & \mathrm{X} \\
\end{array}$ & & $\begin{array}{l}\mathrm{X} \\
\mathrm{X} \\
\mathrm{X} \\
\mathrm{X} \\
\bullet\end{array}$ & & & & & \\
\hline & NN19 & $\begin{array}{l}5-1,147-148 \\
5-2,35-36\end{array}$ & $\mathrm{X}$ & & $\begin{array}{ll}X & X \\
\bullet & X \\
\end{array}$ & & & & & \\
\hline \multirow{5}{*}{ 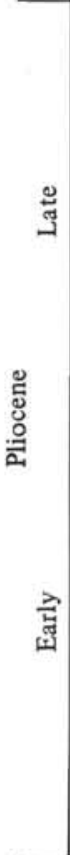 } & NN $18 ?$ & $\begin{array}{l}5-2,52-53 \\
5-2,148-149\end{array}$ & $\mathrm{X}$ & & $\bullet$ & $\bullet$ & $\bullet$ & & $\mathrm{X}$ & $\mathrm{X}$ \\
\hline & NN $16 / 17$ & $\begin{array}{l}5-3,7-8 \\
5-4,35-36 \\
5-4,125-126 \\
5-5,60-61 \\
5, \text { CC } \\
6-1,115-116 \\
6-2,43-44 \\
6-2,96-97 \\
6-3,8-9 \\
6-3,123-124 \\
6-4,45-46\end{array}$ & $\begin{array}{l}X \\
X \\
X \\
X\end{array}$ & & $\begin{array}{l}\mathrm{O} \\
\mathrm{O} \\
\mathrm{O} \\
\mathrm{O} \\
\mathrm{O} \\
\dot{0} \\
\mathrm{O} \\
\dot{0} \\
\dot{0} \\
\mathrm{O}\end{array}$ & $\begin{array}{l}0 \\
0 \\
0 \\
0 \\
0 \\
\\
\vdots \\
0 \\
0 \\
0\end{array}$ & $\begin{array}{l}\dot{0} \\
\dot{0} \\
\dot{0}\end{array}$ & & $\begin{array}{l}\mathrm{X} \\
\dot{\mathrm{x}} \\
\bullet \\
\end{array}$ & $\begin{array}{l}\mathrm{X} \\
\mathrm{X} \\
\mathrm{X} \\
\mathrm{X} \\
\mathrm{O} \\
\bullet \\
\dot{0} \\
\dot{0} \\
\mathrm{O} \\
\bullet\end{array}$ \\
\hline & NN 15 & $\begin{array}{l}6-5,38-39 \\
6-5,110-111 \\
6-6,20-21 \\
7-3,96-97 \\
7-5,42-43\end{array}$ & & & $\begin{array}{l}\mathrm{O} \\
\mathrm{O} \\
\dot{\mathrm{X}} \\
\bullet\end{array}$ & $\begin{array}{ll}\bullet & \\
0 & \dot{X} \\
\mathrm{X} & \mathrm{X} \\
\bullet & \mathrm{X} \\
\end{array}$ & $\begin{array}{l}\dot{0} \\
\dot{x} \\
\end{array}$ & & $\begin{array}{l}\mathrm{X} \\
\mathrm{X} \\
\bullet\end{array}$ & $\begin{array}{ll} & \\
: & \bullet \\
\dot{X} & \mathrm{X} \\
\end{array}$ \\
\hline & NN 13 & $\begin{array}{l}8-1,108-109 \\
8-2,42-43 \\
8-3,37-38 \\
8-4,26-27 \\
9-1,130-131 \\
\end{array}$ & $\begin{array}{l}\mathrm{X} \\
\mathrm{X} \\
\mathrm{X} \\
\mathrm{X} \\
\mathrm{X} \\
\mathrm{X}\end{array}$ & $\begin{array}{l}X \\
X \\
X \\
X \\
X\end{array}$ & $\begin{array}{l}\mathrm{X} \\
\bullet \\
\dot{\mathrm{x}}\end{array}$ & \begin{tabular}{|ll} 
& $\mathrm{X}$ \\
$\mathrm{X}$ & $\mathrm{X}$ \\
& $\mathrm{X}$ \\
$\bullet$ & $\mathrm{X}$ \\
\end{tabular} & $\begin{array}{l}\mathrm{X} \\
\bullet \\
\mathrm{X} \\
\mathrm{X}\end{array}$ & & $\begin{array}{l}x \\
x\end{array}$ & $\begin{array}{l}\mathrm{X} \\
\dot{\mathrm{X}} \\
\mathrm{X} \\
\bullet\end{array}$ \\
\hline & NN1 2 & $\begin{array}{l}9-2,5-6 \\
9-3,16-17 \\
9-4,130-131 \\
10, \mathrm{CC} \\
11-1,86-87\end{array}$ & & : & $\begin{array}{l}\mathrm{X} \\
\mathrm{X}\end{array}$ & $\begin{array}{ll}\dot{0} & \bullet \\
\dot{x} & \vdots \\
& \dot{x}\end{array}$ & $\begin{array}{ll}X & X \\
\bullet & X \\
\bullet & X\end{array}$ & & $\mathrm{X}$ & $\begin{array}{l}\mathrm{X} \\
\mathrm{X} \\
\bullet \\
\mathrm{X}\end{array}$ \\
\hline
\end{tabular}

The Discoaster brouweri Zone (NN 18) occurs from Core 4 to Sample 6, CC. Discoasters are rare or missing in the upper part of this zone. Nannofossils in the sapropel layers are slightly etched. Cores 7 and 8 belong to the Discoaster surculus/Discoaster pentaradiatus Zone (NN 16/NN 17). Discoasters are rare or missing in the upper part of this zone, but become frequent in the lower part.

Thickness of the lower Pliocene zones is reduced; Discoaster tamalis and Discoaster asymmetricus are common in the Reticulofenestra pseudoumbilica Zone (NN 15) of Sample 9, CC.

The Discoaster asymmetricus Zone (NN 14) extends from Sample 10, CC to Section 11-1, and the Ceratolithus rugosus Zone (NN 13) extends from Section 11-2 to Section 11-4. Coccoliths in the sapropel layers are slightly etched, and discoasters are often broken.

The interval from Sample 11-4, 48-49 $\mathrm{cm}$ to Sample 11, CC belongs to the Ceratolithus tricorniculatus Zone (NN 12). Sediments are rich in well-preserved nannofossils; coccoliths are etched and partially diminished by dissolution in the sapropel layers, and there is an enrichment in discoasters (Table 8).

\section{HOLE 378A}

$\left(35^{\circ} 55.67^{\prime} \mathrm{N}, 2^{\circ} 06.97^{\prime} \mathrm{E}\right.$; water depth; $\left.1835 \mathrm{~m}\right)$

A Pleistocene diversified nannofossil assemblage of the Pseudoemiliania lacunosa Zone (NN 19) is present in Core 1. Sediments contain abundant well-preserved nannofossils. Pebbles of different colors in Core 1, 


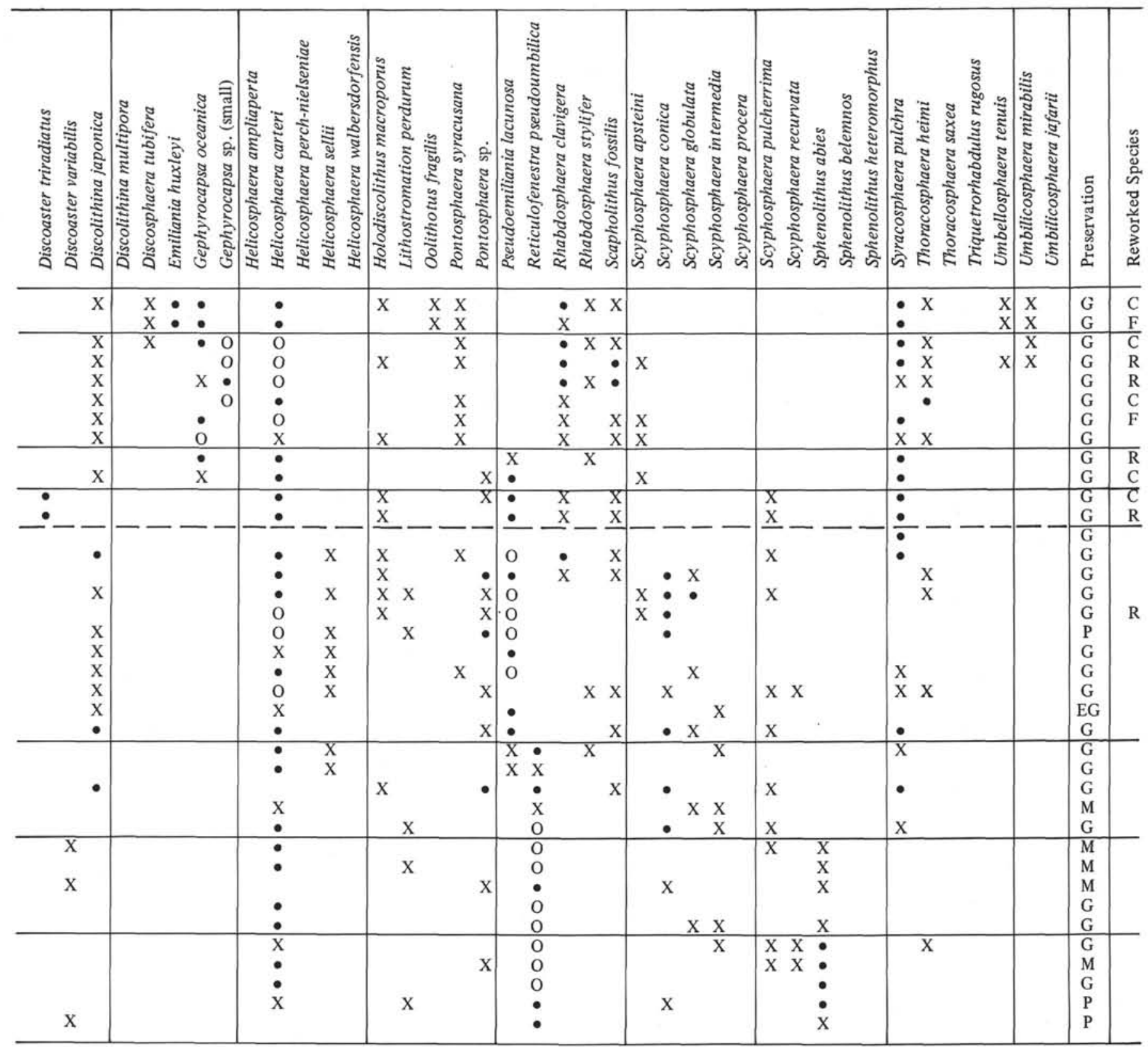

section 2 and the upper part of section 3 contain the same assemblage. Few reworked Neogene species were observed.

Lower Pliocene sediment occurs in Cores 2 and 3 (NN 14 to NN 13), in a strongly reduced sequence. The Ceratolithus rugosus Zone (NN 13) is distinguished by the abundance of scyphospheres and discoasters. This zone is underlain by gypsum (Table 9).

\section{REMARKS ON THE DISTRIBUTION OF NANNOFOSSILS IN NEOGENE SEDIMENTS OF THE MEDITERRANEAN}

Lower Miocene sediment was recovered at Sites 372 and 375. There are few nannofossils in the lower part of the drilled section of the thick Burdigalian sequence at Site 372, but they are more abundant in the upper part of the Burdigalian. Reworked species are less common in the upper part of the Burdigalian and are almost completely missing in the Langhian. Oldest sediments recovered at Site 372 probably belong to the upper part of the Triquetrorhabdulus carinatus Zone (NN 1). Zonal boundaries in the lower Miocene at Site 372 cannot be precisely fixed according to the standard nannofossil zonation, because the index fossils occur only sporadically or are absent.

The absence of Triquetrorhabdulus carinatus in most parts of the Mediterranean and the Paratethys, the scarcity of Discoaster druggii, as well as the absence of Sphenolithus belemnos at Site $\mathbf{3 7 2}$ may be a restit of climate. All these species are common in tropical and subtropical regions. Only a few specimens of Tri- 
TABLE 6

Nannofossil Distribution at Site 375

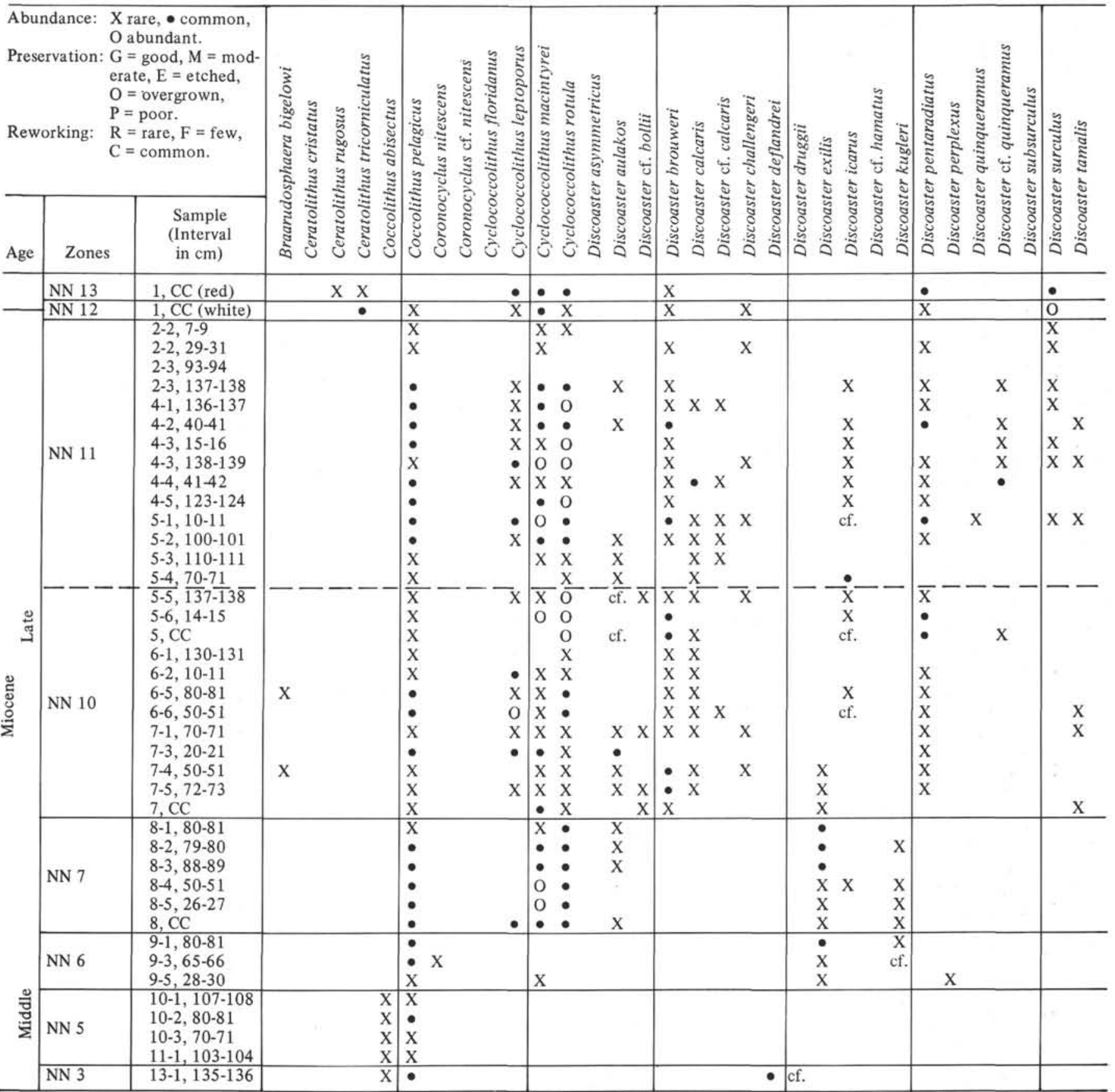

quetrorhabdulus carinatus are reported by Martini (1974) from Spain; occurrence of Sphenolithus belemnos is noted by Sanfilippo et al. (1973) from Italy, and is common in the lower Miocene sediments at Site 375 (Levantine Basin) and in land sections of Cyprus (Müller, unpublished data). Very few specimens of Sphenolithus belemnos were found in the Paratethys.

The stratigraphic interval of the Helicosphaera ampliaperta Zone (NN 4) and Sphenolithus heteromorphus Zone (NN 5) is well documented in the Mediterranean, and zonal boundaries are easily recognized. The nannofossil assemblages correspond to those described from other areas and indicate that a widespread open-marine environment, related to the important middle Miocene transgression and probably resulting from climatic changes, existed. Similar assemblages, although somewhat restricted, are also known from North Europe (Martini and Müller, 1973) and the Paratethys (Martini and Müller, 1975). Sphenolithus heteromorphus appeared later in the Paratethys.

Middle and upper Miocene zonal boundaries, defined by the index fossils given in the standard nannofossil zonation, are difficult to determine in the Mediterranean, since some of these fossils are absent or scarce. Because of their scarcity, the first occurrence of a species in the core material does not always represent 


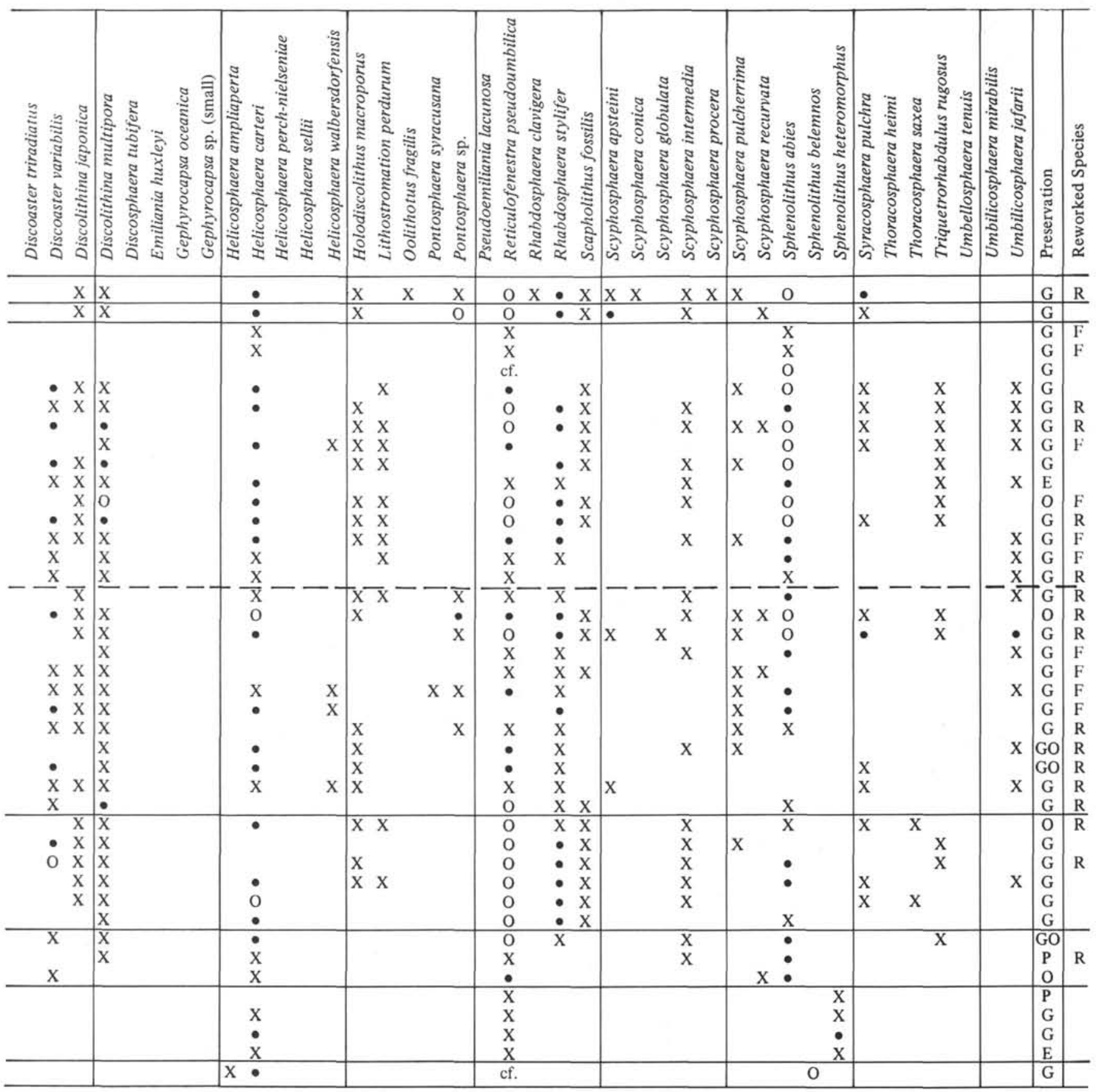

its first stratigraphic occurrence. These difficulties are probably caused by a more restricted influence of the open ocean, lower water temperature, and a more regional development of nannofossil assemblages. Difficulties are also caused by bad preservation, mainly of discoasters, the most important group for the zonation, and/or the often large amount of reworked species, reflecting increased tectonic activities in some regions. In addition, discoasters often are not typically developed. Their shapes are slightly different from those known from tropical areas. This makes their exact identification difficult in some cases.
Middle Miocene sediments in general are rich in nannofossils. The coccoliths are well preserved; the discoasters are often heavily overgrown. The assemblages consist of such long-ranging species as Coccolithus pelagicus, Helicosphaera carteri, Cyclococcolithus macintyrei, Sphenolithus abies, Reticulofenestra pseudoumbilica, Rhabdosphaera stylifer, Discolithina multipora, Cyclococcolithus rotula. Variable abundances of discoasters may indicate climatic fluctuations. Except in some horizons they are usually uncommon in the middle Miocene and are extremely rare or missing in this stratigraphic interval in the Paratethys. Helicos- 
TABLE 7

Nannofossil Distribution at Site 376

\begin{tabular}{|c|c|c|c|c|c|c|c|c|}
\hline \multicolumn{3}{|c|}{$\begin{array}{ll}\text { Abundance: } & \mathrm{X}_{\mathrm{ra}} \\
& \mathrm{O} \text { a } \\
\text { Preservation: } & \mathrm{G}= \\
& \text { erat } \\
& \mathrm{O}= \\
& \mathrm{P}= \\
\text { Reworking: } & \mathrm{R}=\end{array}$} & \multirow{2}{*}{ 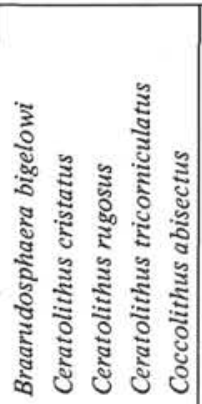 } & \multirow{2}{*}{ 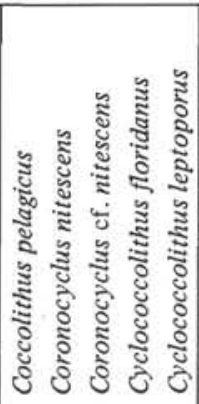 } & \multirow{2}{*}{ 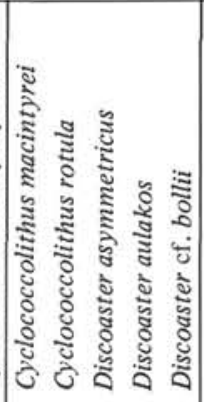 } & \multirow{2}{*}{ 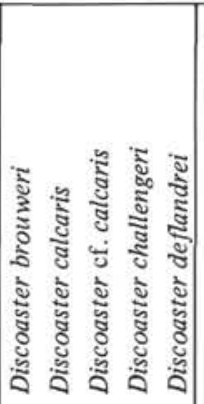 } & \multirow{2}{*}{ 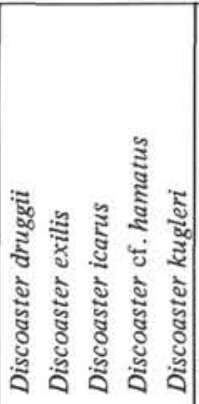 } & \multirow{2}{*}{ 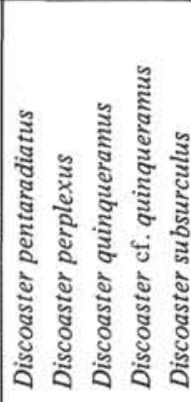 } \\
\hline Age & Zones & $\begin{array}{l}\text { Sample } \\
\text { (Interval } \\
\text { in } \mathrm{cm} \text { ) }\end{array}$ & & & & & & \\
\hline \multirow{3}{*}{ 常 } & NN 21 & $\begin{array}{l}1-1,51-52 \\
1-3,26-27 \\
1-5,130-131 \\
1, \mathrm{CC}\end{array}$ & $\begin{array}{l}X \quad X \\
X \\
X\end{array}$ & $\mathrm{x}$ & & & & \\
\hline & \multirow[t]{2}{*}{ NN 20} & $\begin{array}{l}2-1,132-133 \\
2-2,120-121 \\
2-4,66-67 \\
2-4,146-147 \\
3-2,29-30 \\
3-4,120-121\end{array}$ & $\begin{array}{r}X X \\
X \\
\text { - } X\end{array}$ & $\begin{array}{l}\dot{0} \\
\mathrm{X} \\
\mathrm{X} \\
\mathrm{X} \\
0\end{array}$ & & & & \\
\hline & & $\begin{array}{l}3-5,126-127 \\
4-1,95-96 \\
4-2,60-61 \\
5-1,68-69 \\
5-2,40-41\end{array}$ & $\begin{array}{l}x--1 \\
x \times \\
x \\
x \\
\end{array}$ & $\ddot{x}$ & & & & \\
\hline & NN 18 & $\begin{array}{l}5-3,20-21 \\
5-3,100-101\end{array}$ & $\begin{array}{l}X \\
X\end{array}$ & & $\begin{array}{l}0 \\
\end{array}$ & 0 & & $\mathrm{X}$ \\
\hline & NN $16 / 17$ & $\begin{array}{l}5-4,10-12 \\
5-4,110-111\end{array}$ & $\mathrm{X}$ & & $\begin{array}{ll}\bullet & X \\
0 & X \\
\end{array}$ & $\dot{x}$ & & $\dot{x}$ \\
\hline \multirow{6}{*}{ 䒿 } & NN 15 & $\begin{array}{l}5-5,52-53 \\
5-5,80-82 \\
\end{array}$ & $\begin{array}{l}\mathrm{X} \\
\mathrm{X}\end{array}$ & $\mathrm{X}$ & $\begin{array}{lll}- & X & X \\
\bullet & & \bullet \\
\end{array}$ & $\mathrm{X}$ & & $\mathrm{O}$ \\
\hline & NN 14 & $\begin{array}{l}5-5,88-90 \\
5-5,91-92 \\
\end{array}$ & $\begin{array}{ll}X & X \\
X & X \\
\end{array}$ & & $\begin{array}{ll}X & X \\
\bullet & \bullet \\
\end{array}$ & & & : \\
\hline & NN 13 & $\begin{array}{l}5-5,99-100 \\
5-5,109-111 \\
\end{array}$ & $\begin{array}{ll}\mathrm{X} & \mathrm{X} \\
\mathrm{X} & \bullet \\
\end{array}$ & $\begin{array}{l}\mathrm{X} \\
\mathrm{X} \\
\end{array}$ & 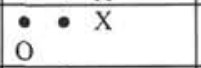 & $\mathrm{X}$ & & $\begin{array}{l}0 \\
0\end{array}$ \\
\hline & NN 12 & $\begin{array}{l}5-5,127-129 \\
5, \mathrm{CC}\end{array}$ & $\dot{\mathrm{X}}$ & $\hat{x}$ & $\because 0$ & 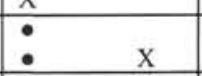 & & O \\
\hline & NN 19 & $6-1$ to $6-3,95$ & & & & & & \\
\hline & NN 12 & $\begin{array}{l}6-3,100-101 \\
6-4,120-121 \\
7-1,31-32 \\
\end{array}$ & $\begin{array}{l}\dot{0} \\
\mathrm{X} \\
\mathrm{X}\end{array}$ & $\dot{x}$ & 0 & $\begin{array}{l}\mathrm{X} \\
\mathrm{X} \\
\bullet\end{array}$ & & $\begin{array}{l}\mathrm{X} \\
\mathrm{X}\end{array}$ \\
\hline 窇 & NN 11 & $\begin{array}{l}7-1,75-76 \\
8-1,103-104 \\
8-3,20-21 \\
17-1,121-122\end{array}$ & & $\mathrm{x}$ & $\begin{array}{ll}\mathrm{X} & \mathrm{X} \\
\mathrm{X} & \mathrm{X}\end{array}$ & $\mathrm{X}$ & & $\mathrm{X}$ \\
\hline
\end{tabular}

phaera walbersdorfensis seems to be typical in the Discoaster exilis Zone (NN 6) and the Discoaster kugleri Zone (NN 7). This species occurs in the middle Miocene of the Paratethys and in samples from Trinidad (Müller, 1974).

Scyphospheres are scarce throughout the middle and upper Miocene. Thoracosphaera saxea is common in some layers at Site 375 , but sporadic in the western Mediterranean. This may indicate slightly warmer water in the eastern Mediterranean.

Discoaster kugleri is rare and is not always typically developed. The forms of the Mediterranean have longer rays than those of the tropical region. This may be a function of lower water temperature. Catinaster coalitus seems to be missing in the Mediterranean. The middle Miocene discoaster assemblages are distinguished by species of the Discoaster variabilis group, Discoaster exilis, Discoaster subsurculus, and Discoaster aulakos.
Sediments of the uppermost Miocene (upper part of the Discoaster quinqueramus Zone, NN 11, corresponding to the Messinian) are often distinguished by a marked decrease of nannofossils, as well as a decrease of species diversity. The depositional conditions of the Messinian were different in different parts of the Mediterranean region, and ranged from marine to continental. Turbidite sequences, rich in reworked species of Cretaceous to middle or even upper Miocene species, represent the Messinian, or have been interbedded with evaporitic sequences, which indicate increasing tectonic activities (basin deepening, with increasing submarine slopes, and/or land uplift, causing a stronger erosive activity, followed by a quieter period during which evaporites were formed). In other basins, interbeds of marls rich in marine nannofossil assemblages indicate an influx of normal marine water. They are interbedded with the evaporitic sequences or with brackish to continental marls. This indicates that 


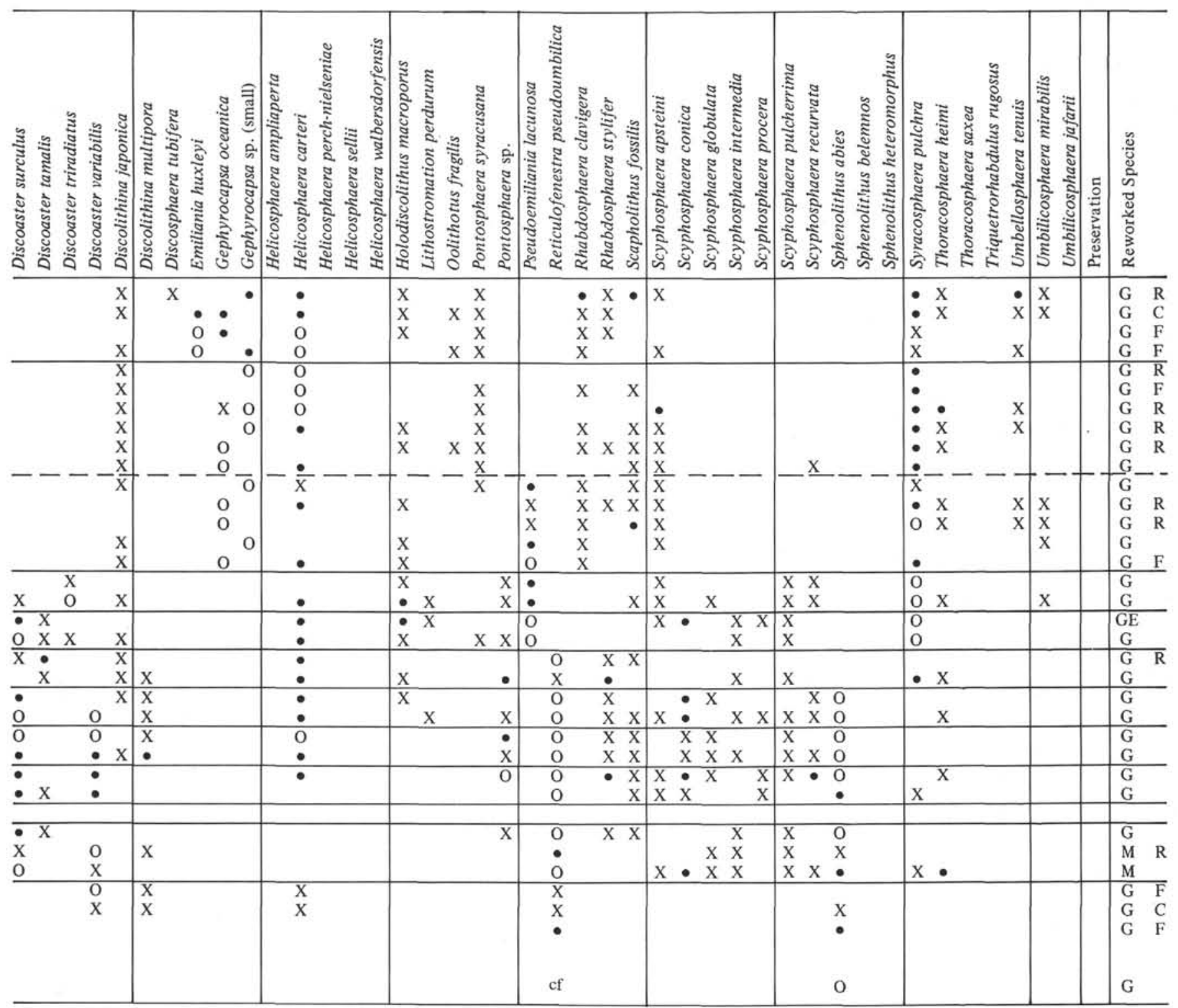

the Mediterranean was not completely separated from the open ocean during the uppermost Miocene. These interbeds may show changes of sea level caused by climatic or tectonic events. But there are also regions where open marine conditions have existed throughout the Messinian. Investigations in the Vera Basin of Spain (Montenat et al., in press) show rich diversified nannofossil assemblages with few specimens of Ceratolithus tricorniculatus and Discoaster quinqueramus, overlain by lower Pliocene marls which contain increased numbers of discoasters and Ceratolithus tricorniculatus.

The fine laminated upper Miocene sediments in Sections 9-1 and 9-2 at Site 372 (Discoaster quinqueramus Zone, NN 11) consist of alternating white and dark layers. The white layers are extremely rich in nannofossils, and contain an almost monospecific as- semblage of Sphenolithus abies and/or a very small Reticulofenestra $\mathrm{sp}$. This reduced assemblage indicates abnormal conditions, in this case probably a hypersaline milieu, in which only few species can survive. Species of these white layers are sometimes abnormal in size (either smaller or larger) compared with specimens representing normal marine conditions.

The dark layers contain more clay, detrital material, and reworked species; nannofossils are less common, but the assemblages are more diversified, indicating an influx of normal marine water. The assemblages of the gray layers consist of Coccolithus pelagicus, Reticulofenestra pseudoumbilica, Helicosphaera carteri, Sphenolithus abies, Cyclococcolithus macintyrei and Discolithina multipora and few discoasters. Few Ceratolithus tricorniculatus were found in this fine laminated section. Same nannofossil assemblages are described by 
TABLE 8

Nannofossil Distribution at Site 378

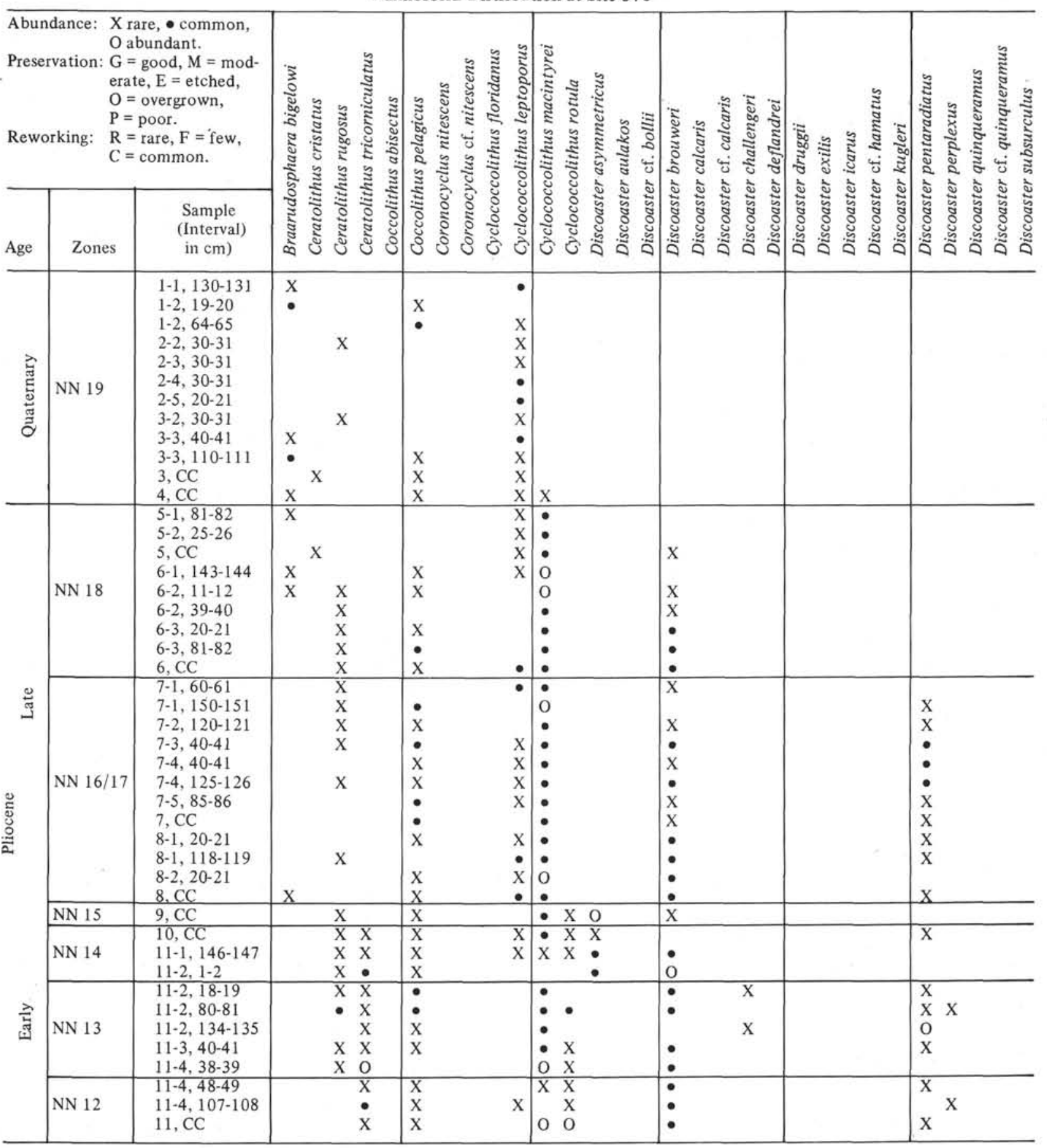

Rouchy (1976) from the fine laminated sediments of the upper Miocene of Sicily (Eraclea Minoa, Montedoro). Fine laminated sediments distinguished by monospecific nannofossil assemblages in the white layers are also reported from the Jurassic (Müller and Blaschke, 1969a; Bernier et al., 1972; Noê1, 1972), from the Oligocene (Müller and Blaschke, 1971; Busson and Noêl, 1972; Doebl et al., personal communication), from the Miocene (Best and Müller, 1972), and from the Pleistocene from the Black Sea (Müller and Blaschke, 1969b; Bukry et al., 1970).

Pliocene sediments were deposited in an open marinè environment. Sediments contain abundant nanno- fossils and the assemblages are highly diverse. Reworked species in general are missing or are sporadic. Differences in the distribution of nannofossils in the western and eastern Mediterranean are most distinct in the upper Pliocene and Quaternary, as a result of the different influence of Atlantic water masses in both regions. The Pliocene sequence, mainly the lower Pliocene, is sometimes extremely compressed (Sites 372,376 , and 378 ), restricting zones to a few centimeters.

Evidence of climatic fluctuations occurs in the Pliocene sediments (more distinctly in the upper Pliocene) as variations in the abundance of discoasters and 
TABLE 8 - Continued

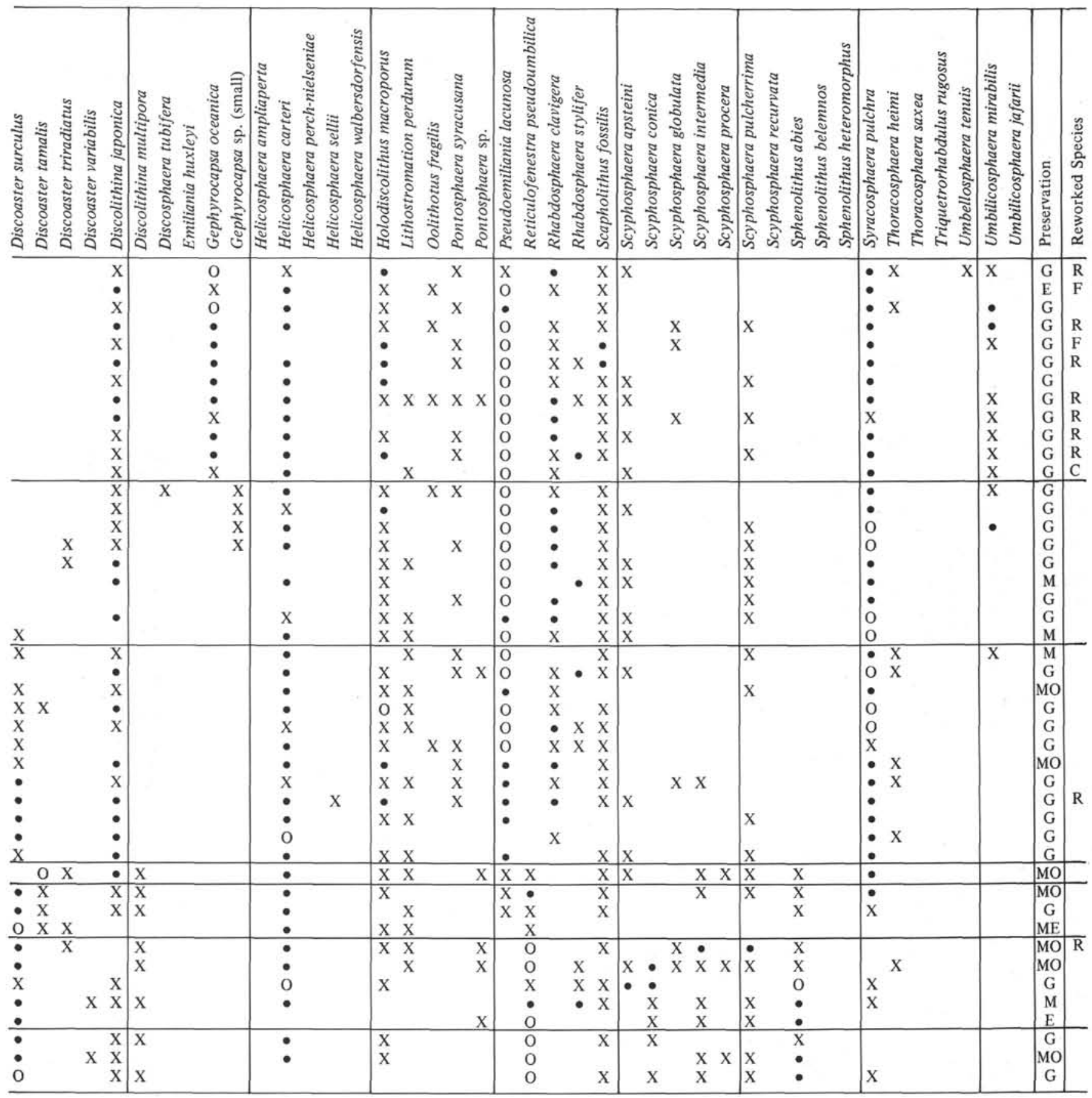

scyphospheres. Both groups are abundant in the lowermost Pliocene (Ceratolithus tricorniculatus) Zone (NN 12) and Ceratolithus rugosus Zone (NN 13), indicating a warmer water temperature; nannofossils are less abundant in the Discoaster asymmetricus Zone (NN 14). They are again abundant in the Reticulofenestra pseudoumbilica Zone (NN 15) and the lower to middle part of the Discoaster surculus Zone/Discoaster pentaradiatus Zone (NN 16/NN17). Climatic deterioration is indicated again in the upper part of the Discoaster surculus/Discoaster pentaradiatus Zone (NN 16/NN 17 ), and in the lower- and uppermost part of the Discoaster brouweri Zone (NN 18). These results are comparable to those of Ciaranfi and Cita (1973), deduced from changes of foraminifer assemblages. Climatic changes during the Pliocene were more distinct than during the Pleistocene, as regards the nannoplankton. All these phenomena were more distinct in the western Mediterranean, owing to the stronger influence of Atlantic water masses there.

Ceratoliths, the index fossils for the lower Pliocene, are extremely scarce in some sections. Their occurrence is strongly controlled by ecological variables. They occur commonly in tropical regions, and are rare or missing in cold water or in near-shore or shallow water sediments. Ceratolithus tricorniculatus, which first oc- 
TABLE 9

Nannofossil Distribution at Site 378A

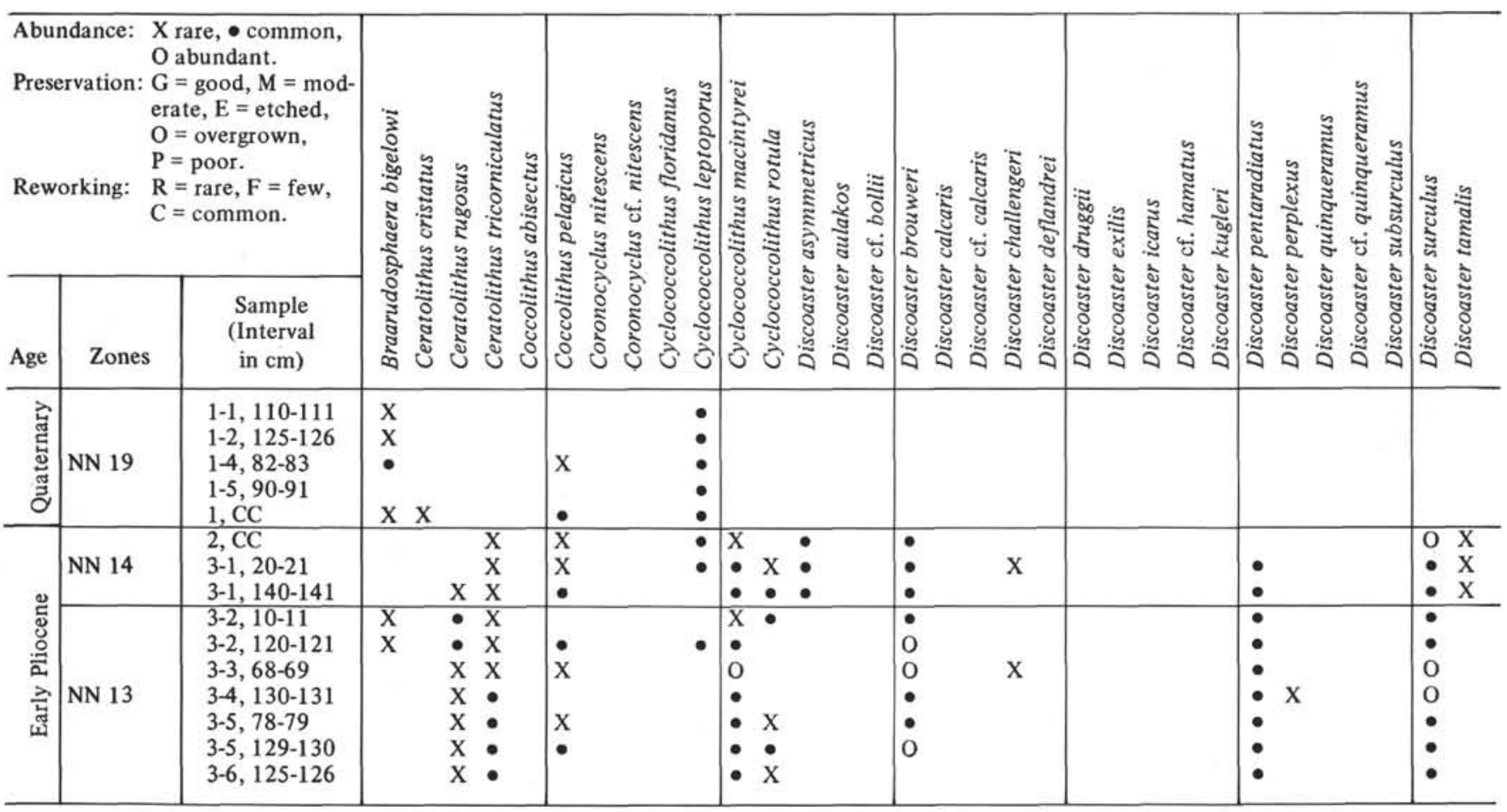

curs in the lower part of the Discoaster quinqueramus Zone (NN 11) of the upper Miocene, is generally more abundant than other species of this group. It is rare or missing in the reduced assemblages of the Messinian, and it becomes frequent in the lower Pliocene (Ceratolithus tricorniculatus Zone [NN 12] and Ceratolithus rugosus Zone [NN 13]). Ceratolithus tricorniculatus is rare in the Discoaster asymmetricus Zone (NN 14). Both varieties (with and without the horn) were found in the samples.

Ceratolithus amplificus (= C. acutus Gartner and Bukry), which is used by Bukry (1973) to define the Ceratolithus acutus Subzone, occurs only sporadically in the Mediterranean and is not useful in this region (Bukry, 1973; Schmidt, 1973; this report). Only two specimens were found, together with Ceratolithus tricorniculatus in the material of Leg 42A (Site 372, Discoaster quinqueramus Zone, NN 11). Ceratolithus rugosus is rare in the lower Pliocene (Ceratolithus rugosus Zone [NN 13] and Discoaster asymmetricus Zone [NN 14]). Because of the scarcity of this species, in some cases it is difficult to determine the base of the Ceratolithus rugosus Zone (NN 13). Ceratolithus cristatus first occurs in the upper Pliocene.

Significant differences in the abundance of discoasters, at least in the upper Pliocene, exist between the western and eastern Mediterranean. They are abundant throughout the Pliocene of the Levantine Basin (Site 376), rare in the uppermost part of the Discoaster brouweri Zone (NN 18) and in some horizons of the lowermost part of this zone and the uppermost part of the Discoaster surculus/Discoaster pentaradiatus Zone (NN 16/NN 17) in the Ionian and the Aegean seas. They occur only sporadically or are missing throughout the Discoaster brouweri Zone (NN 18) and the uppermost part of the Discoaster surculus/Discoaster pentaradiatus Zone (NN 16/NN 17) in the western Mediterranean. Their extinction is therefore not very useful for precise determination of the Pliocene/Pleistocene boundary in this region. In this report the boundary is determined by the last occurrence of Cyclococcolithus macintyrei.

Discoaster tamalis is abundant in some horizons of the Reticulofenestra pseudoumbilica Zone (NN 15), also reported by Schmidt (1973). This species is rare in the Discoaster surculus Zone (NN 16), and cannot be used to determine the Discoaster tamalis Subzone of Bukry (1973) in the Mediterranean.

Discoaster surculus is usually rare in the uppermost part of the Discoaster surculus/Discoaster pentaradiatus Zone (NN 16/NN 17), at least in the western Mediterranean, but is abundant below the middle part of this zone. It seems to become extinct at the same level as Discoaster pentaradiatus; consequently, these zones are combined in this report.

Discoaster pentaradiatus occurs frequently in several horizons. A very large variety of this species occurs in the lower Pliocene (NN 12) of the Levantine Basin. In the upper Miocene sediments, specimens are sometimes very small, with a very indistinct bifurcation of the raytips; they are difficult to separate from atypical Discoaster quinqueramus.

The abundance of Discoaster triradiatus is typical for the Discoaster brouweri Zone (NN 18); farther down, this species was found only sporadically.

Small specimens of Reticulofenestra pseudoumbilica are characteristic of the uppermost part of Zone NN 15. An overlap of Pseudoemiliania lacunosa (small, 


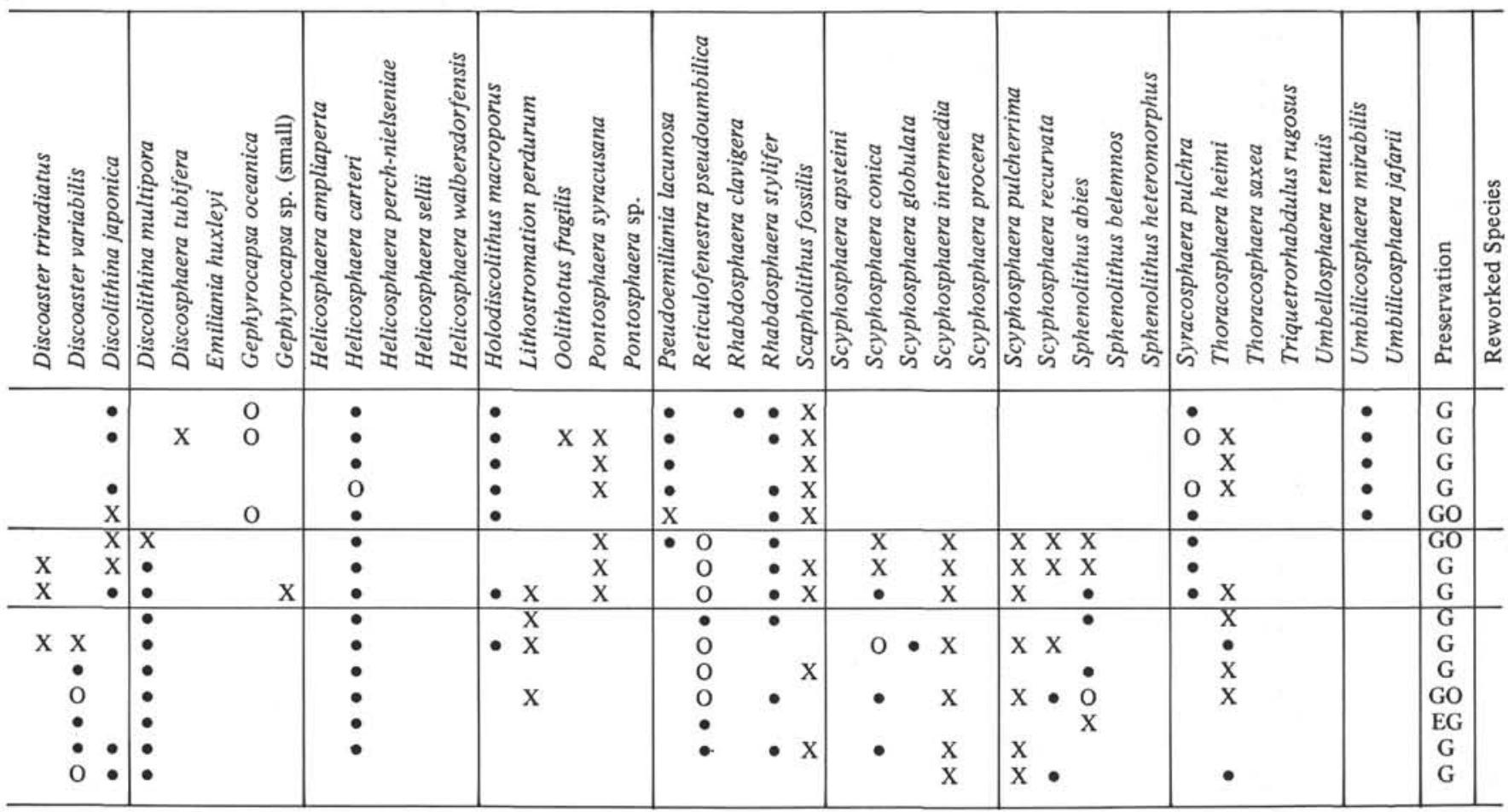

slightly oval) and Reticulofenestra pseudoumbilica was observed in the uppermost part of the Reticulofenestra pseudoumbilica Zone (NN 15).

Scyphospheres are common in the upper Pliocene (NN 15, NN 16, lower part of Zone NN 18 in the Levantine Basin and Aegean Sea) and in the lower Pliocene (NN 13); they are rare throughout the Miocene sediments.

A small species of the genus Gephyrocapsa is present in the Discoaster surculus/Discoaster pentaradiatus Zone (NN 16/NN 17), and even in the lower Pliocene (NN 13 and NN 14 at Site 378) a primitive form was observed, so that species of this genus can no longer be regarded as typical Pleistocene forms. Thierstein (1974) also reports the presence of Gephyrocapsa sp. below the extinction level of discoasters from the Indian Ocean, and Rio (1974) noted them from Le Castella and Santa Maria di Catanzaro.

Several sapropel layers occur within the Pliocene sequence at Site 374 (Ionian Sea) and at Site 378 (Aegean Sea). The nannofossil contents of these layers are extremely variable. In some of them coccoliths have been almost completely dissolved; in others discoasters have been enriched by selective dissolution of the more fragile coccoliths. But there are also sapropel layers rich in nannofossils with no signs of dissolution. Sapropel layers recovered in the Ceratolithus tricorniculatus Zone (NN 12) in Sample 10, CC and in Core 11 at Site 374 are distinguished by the abundance of large, mostly broken, discoasters.

Quaternary sediments penetrated during Leg 42A are generally abundant in nannofossils. The assemblages belong to the transitional and subtropical zone (McIntyre and Bé, 1967), and are very diverse. The assemblages of the western and eastern Mediterranean differ slightly (Müller, 1972), probably as a result of descreasing influence of Atlantic water masses in the eastern Mediterranean. Umbilicosphaera mirabilis, Umbellosphaera tenuis, and Oolithotus fragilis, more typical for the assemblage of the subtropical zone, are rare or missing in the western Mediterranean but are common in the eastern Mediterranean sediments. Coccolithus pelagicus, an indicator of cooler water, is restricted to some horizons in the eastern Mediterranean (Müller, 1972 ) but occurs throughout the Quaternary in some regions of the western Mediterranean. It was probably brought in by currents from the Atlantic (Sites 371 and 372, Müller, 1972). Detailed investigations of piston cores (taken during the cruise of the Meteor in 1971) have shown that Coccolithus pelagicus is not always autochthonous in the sediments. A correlation exists between the number of Coccolithus pelagicus and the amount of reworked species from the Cretaceous and Tertiary. This observation was made mainly from Ionian Sea sediments in which a large number of reworked species are present.

Quaternary sediments are often characterized by turbidites (Site 374) containing tunicate spicules and numerous reworked species. The nannofossils are concentrated in the fine fraction of the turbidites and diluted in the coarse-grained fraction.

The Quaternary sequence of the eastern Mediterranean is characterized by interbedding of different sapropel layers. The preservation of nannofossils is excellent in these layers, where Helicosphaera carteri, Rhabdosphaera stylifer, and Gephyrocapsa oceanica are often the most common species. Also, Umbellosphaera irregularis, a species of the tropical zone, which may 
indicate increasing water temperature during deposition of the sapropels, was found (Müller, 1972). Until now it has not been possible to correlate these layers by several typical nannofossil assemblages. At Site 374 and Site 378, reworked species are far less common in the sapropel layers than in the sediments directly below. This may indicate a change of current patterns. Holocene sediments, especially of the eastern Mediterranean, are distinguished by many holococcoliths, which are normally dissolved in deep-sea sediments. They are also common in the Red Sea (Müller, in press).

In the lowermost part of the Pseudoemiliania lacunosa Zone (NN 19), a distinct horizon, rich in very large specimens of Braarudosphaera bigelowii, occurs at Site 371. This horizon corresponds to that recovered during Leg 13 at Site 132 in the Tyrrhenian Sea (Stradner, 1973). A Braarudosphaera bigelowii horizon is also present at Site 378 (Aegean Sea) in the lower Pseudoemiliania lacunosa Zone, but is less distinct. It may be comparable to the horizon reported from Site 130 (Mediterranean Ridge). The abundance of Braarudosphaera bigelowii indicates lower salinity (Bukry, 1974). Braarudosphaera bigelowii horizons are also known from the Black Sea (Bukry, 1974), the middle Oligocene (Doebl et al., 1976), the upper Miocene (NN 11) in the section of Agata Fossili (Müller, unpublished data), and from the lower middle Oligocene of the Atlantic (Maxwell et al., 1970). Takayama (1972) described the occurrence of recent sediments rich in Braarudosphaera bigelowii from the Sendai Bay, Japan, deposited in near-shore areas influenced by drainage of rivers. The horizons in the Mediterranean near the Pliocene/Pleistocene boundary probably indicate a decreasing salinity caused by a strong influx of fresh water. The fresh water was supplied on one hand from the Black Sea, and on the other hand from circum-Mediterranean rivers fed by meltwater and also by an increased runoff in pluvial regions. All of this, coupled with the distinct decrease of Coccolithus pelagicus (cold water) at the Pliocene/Pleistocene boundary in the Mediterranean (more distinct in the western Mediterranean), confirms the view of Emiliani et al. (1961) and of McIntyre et al. (1967) that no major cooling occurred at the beginning of the Pleistocene, as would be suspected by the occurrence in the Mediterranean of northern immigrants like Hyalinea balthica and Arctica islandica.

The Pliocene/Pleistocene boundary in Leg 42A material is defined by the extinction of Cyclococcolithus macintyrei (Bizon and Müller, this volume). This is a very distinct boundary in the Mediterranean. No specimens were found above the last occurrence of this species, except in a few samples at Sites 371,374 , and 378 , where a few specimens, together with other reworked Neogene species, were observed. Investigations of deep-sea cores from other areas have shown that the highest determined extinction level of discoasters lies just above the top of the Olduvai event (Berggren et al., 1967), which corresponds to the extinction of Cyclococcolithus macintyrei (Gartner, 1973). Studies of the Leg 42A material show that recognition of the Pliocene/Pleistocene boundary by the extinction of Discoaster brouweri is very uncertain, at least in the western Mediterranean (Sites 371, 372, and 132), where discoasters are extremely rare or missing in several horizons.

\section{ACKNOWLEDGMENTS}

The author wishes to thank Prof. Dr. E. Martini, Frankfurt am Main, and Dr. D. Bukry, La Jolla, California, who read the manuscript of this paper. This investigation was supported by the German Science Foundation.

\section{REFERENCES}

Barbieri, F. and Rio, D., 1974. Calcareous nannoplankton from the Piacenzian (Late Pliocene) of Western Emily: Ateneo Parmense, acta nat., v. 10, p. 29-42.

Berggren, W. A., Phillips, J. D., Bertels, A., and Wall, D., 1967. Late Pliocene-Pleistocene stratigraphy in deep-sea cores from the south-central North Atlantic: Nature, v. 216, p. 253-254.

Bernier, P., Busson, G., Enay, R., and Noël, D., 1972. Les calcaires bitumineux d'Armailles formation laminée du Kimméridgien de la région de Belley (Ain) et leurs conditions de depôt. C. R. Acad. Sci. Paris, V. 274. p. 2925-2928.

Best. G. and Müller, C., 1972. Nannoplankton-Lagen im Unter-Miozän von Frankfurt am Main: Senckenberg. lethaea, v. 53, p. 103-117.

Bukry, D., 1973. Coccolith stratigraphy Leg 13, Deep Sea Drilling Project. In Ryan, W. B. F., Hsü, K. J., et al., Initial Reports of the Deep Sea Drilling Project, Volume 13: Washington (U.S. Government Printing Office), p. 817-822.

1974. Coccoliths as paleosalinity indicators-evidence from Black Sea: Am. Assoc. Petrol. Geol. Mem., v. 20, p. 353-363.

Bukry, D., Kling, S. A., Horn, M. K., and Manheim, F. T., 1970. Geological significance of coccoliths in fine-grained carbonate bands of Postglacial Black Sea sediments: Nature, v. 226, p. 156-158.

Busson, G., and Noël, D., 1972. Sur la constitution et al genèse de divers sédiments finement feuilletés ("laminites"), à alternances de calcaire et de matière organique ou argileuse: C. R. Acad. Sci. Paris, v. 274, p. 3172-3175.

Cati, F. and Borsetti, A. M., 1970. I discoasteridi del Miocene delle Marche: Giorn. Geol., ser. 2, v. 36, p. 617-632.

Ciaranfi, N. and Cita, M. B., 1973. Paleontological evidence of changes in the Pliocene climates. In Ryan, W. B. F., Hsü, K. J., et al., Initial Reports of the Deep Sea Drilling Project, Volume 13: Washington (U.S. Government Printing Office), p. 1387-1399.

Cita, M. B. and Gartner, S., 1973. The stratotype Zanclian foraminiferal and nannofossil biostratigraphy: Riv. Ital. Paleontol., v. 79 , p. 503-558.

Cita, M. B., Stradner, H., and Ciaranfi, N., 1973. Biostratigraphical investigations on the Messinian stratotype and on the overlying "Trubi" Formation: Riv. Ital. Paleontol., v. 79 , p. $393-446$.

Doebl, F., Müller, C., Schuler, M., Sittler, C., and Weiler, H., 1976. Les marnes à foraminifères et les schistes à poissons de Bremmelbach (Bas Rhin). Etude sédimentologique et micropaléontologique. Reconstitution du milieu au début du Rupélien dans le fossé rhénan: Sci. Géol. Bull., v. 29, p. 4.

Emiliani, C., Mayeda, T., and Selli, R., 1961. Paleotemperature analysis of the Plio-Pleistocene section at Le Castella, 
Calabria, south Italy.-Bull: Geol. Soc. Am. Bull., v. 72, p. 679-688.

Gartner, S., Jr., 1973. Absolute chronology of the Late Neogene calcareous nannofossil succession in the Equatorial Pacific: Geol. Soc. Am. Bull., v. 84, p. 2021-2034.

Martini, E., 1968. Calcareous nannoplankton from the type Langhian: Giorn. Geol., ser. 2, v. 35, p. 163-172. , 1971. Standard Tertiary and Quaternary calcareous nannoplankton zonation: Second Plank. Conf. Proc., Roma 1970 , v. 2, p. 739-785.

1975. Calcareous nannoplankton from the type Tortonian. Sixth Congr. C.M.N.S. Proc., Bratislava 1975, v. 1, p. 53-59.

Martini, E. and Bramlette, M. N., 1963. Calcareous nannoplankton from the experimental Mohole drilling: J. Paleontol., v. 37, p. 845-856.

Martini, E., and Müller, C., 1973. Nannoplankton-Gemeinschaften im Miozän and Pliozän des Nordseebeckens: N. Jb. Geol. Paläont. Mh., v. 9, p. 555-564.

1975a. Calcareous nannoplankton and silicoflagellates from the type Ottnangian and equivalent strata in Austria: Sixth Congr. C.M.N.S. Proc., Bratislava 1975, v. 1. 121-123.

1975b. Calcareous nannoplankton from the Karpatian in Austria (Middle Miocene): Sixth Congr. C.M.N.S. Proc., Bratislava 1975, v. 1, p. 125-127.

Maxwell, A. E. et al., 1970. Deep sea drilling in the South Atlantic: Science, v. 168, p. 1047-1059.

McIntyre, A., Bé, A. W. H., and Preikstas, R., 1967. Coccoliths and the Plio-Pleistocene boundary: Progr. Oceanogr., v. 4 , p. $3-25$.

Montenat, C. G., Bizon G., and Bizon, J. J., 1976. Continuité et discontinuité de sédimentation marine Mio-Pliocène en Méditerranée occidentale: Rev. J.F.P., v. 31, p. 613-663.

Müller, C., 1972. Kalkiges Nannoplankton aus Tiefseekernen des Ionischen Meers: "Meteor" Forsch-Ergebnisse, Reihe C, v. 10 , p. $75-95$.

, 1974. Nannoplankton aus dem Mittel-Miozän von Walbersdorf (Burgenland): Senckenberg lethaea, v. 55, p. 389-405.

1975. Calcareous nannoplankton from the type Serravallian: Sixth Congr. C.M.N.S. Proc., Bratislava 1975 , v. 1 , p. $49-52$.

, 1976. Nannoplankton-Gemeinschaften aus dem Jung-Quartär des Golfs von Aden und des Roten Meers: Geol. Jb., D17, p. 33-77.
Müller, G. and Blaschke, R., 1969a. Zur Entstehung des Posidonienschiefers (Lias $\Sigma$ ): Naturwissenschaften, v. 56, p. 635 .

, 1969b. Zur Entstehung des Tiefsee-Kalk schlammes im Schwarzen Meer: Naturwissenschaften, v. 56, p. 561-562.

1971. Coccoliths: important rock-forming elements in bituminous shales of central Europe: Sedimentology, v. 17 , p. $119-124$.

Rio, D., 1974. Remarks on late Pliocene-early Pleistocene calcareous nannofossils stratigraphy in Italy: Ateneo Parmense, acta nat., v. 10, p. 409-449.

Rögl, F. and Müller, C., 1976. Das Mittelmiozän und die Baden-Sarmat Grenze in Walbersdorf (Burgenland): Ann. Naturhist. Mus. Wien, v. 80 , p. 221-232.

Rouchy, J. M., 1976. Mise en évidence de nannoplancton calcaire dans certains types de gypse finement lité (balatino) du Miocène terminal de Sicile et conséquences sur la genèse des evaporites méditerranéennes de cet âge: C.R. Acad. Sci. Paris, v. 282, p. 13-16.

Sanfilippo, A., Burckle, L. H., Martini, E., and Riedel, W. R., 1973. Radiolarians, diatoms, silicoflagellates and calcareous nannofossils in the Mediterranean Neogene: Micropaleontology, v. 19, p. 209-234.

Schmidt, R. R., 1973. A calcareous nannoplankton zonation for Upper Miocene-Pliocene deposits from the southern Aegean area, with a comparison to Mediterranean stratotype localities: Kon. Ned. Akad. Wettensch. Proc., ser. B, v. 76, p. 288-309.

Smith, L. A., 1969. Pleistocene discoasters at the stratotype of the Calabrian stage (Santa Maria di Catanzaro) and at Le Castella, Italy: Gulf Coast Assoc. Geol. Soc. Trans., v. 19, p. $579-583$.

Stradner, H., 1973. Catalogue of calcareous nannoplankton from sediments of Neogene age in the eastern North Atlantic and Mediterranean Sea. In Ryan, W. B. F., Hsü, K. J., et al., Initial Reports of the Deep Sea Drilling Project, Volume 13: Washington (U.S. Government Printing Office), p. 1137-1199.

Takayama, T., 1972. A note on the distribution of Braarudosphaera bigelowi (Gran and Braarud) Deflandre in the bottom sediments of Sendai Bay, Japan: Proc. Paleontol. Soc. Trans., Japan, n.s., v. 87, p. 429-435.

Thierstein, H. R., 1974. Calcareous nannoplankton-Leg 26, Deep Sea Drilling Project. In Davies, T. A., Luyendyk, B. P., et al., Initial Reports of the Deep Sea Drilling Project, Volume 26: Washington (U.S. Government Printing Office), p. 619-668. 